\title{
Review \\ Epigenetic Deregulation of Apoptosis in Cancers
}

\author{
Ezgi Ozyerli-Goknar 1,2 (1) and Tugba Bagci-Onder 1,2,* \\ 1 Brain Cancer Research and Therapy Laboratory, Koç University School of Medicine, Istanbul 34450, Turkey; \\ eozyerli14@ku.edu.tr \\ 2 Research Center for Translational Medicine, Koç University, Istanbul 34450, Turkey \\ * Correspondence: tuonder@ku.edu.tr
}

check for

updates

Citation: Ozyerli-Goknar, E.; Bagci-Onder, T. Epigenetic Deregulation of Apoptosis in Cancers. Cancers 2021, 13, 3210. https:// doi.org/10.3390/cancers13133210

Academic Editor: Alberto Anel

Received: 27 April 2021

Accepted: 11 June 2021

Published: 27 June 2021

Publisher's Note: MDPI stays neutral with regard to jurisdictional claims in published maps and institutional affiliations.

Copyright: (c) 2021 by the authors. Licensee MDPI, Basel, Switzerland. This article is an open access article distributed under the terms and conditions of the Creative Commons Attribution (CC BY) license (https:// creativecommons.org/licenses/by/ $4.0 /)$.
Simple Summary: Disruption of the balance between cell division and cell death (apoptosis) is an extremely important factor contributing to cancer formation and progression. While cancer cells acquire characteristics to divide uncontrollably, they also adopt several mechanisms to escape apoptosis. These mechanisms appear through genetic alterations, by selection of new mutations. However, perhaps a more favorable approach for cancer cells is suppressing apoptosis at the gene expression level, through epigenetic alterations. In this review, we present an overview of how the apoptotic program components within cancer cells are deregulated at an epigenetic level. We also provide an update on the potential use of epigenetic modifier drugs (Epi-drugs) as anti-cancer agents.

Abstract: Cancer cells possess the ability to evade apoptosis. Genetic alterations through mutations in key genes of the apoptotic signaling pathway represent a major adaptive mechanism of apoptosis evasion. In parallel, epigenetic changes via aberrant modifications of DNA and histones to regulate the expression of pro- and antiapoptotic signal mediators represent a major complementary mechanism in apoptosis regulation and therapy response. Most epigenetic changes are governed by the activity of chromatin modifying enzymes that add, remove, or recognize different marks on histones and DNA. Here, we discuss how apoptosis signaling components are deregulated at epigenetic levels, particularly focusing on the roles of chromatin-modifying enzymes in this process. We also review the advances in cancer therapies with epigenetic drugs such as DNMT, HMT, HDAC, and BET inhibitors, as well as their effects on apoptosis modulation in cancer cells. Rewiring the epigenome by drug interventions can provide therapeutic advantage for various cancers by reverting therapy resistance and leading cancer cells to undergo apoptotic cell death.

Keywords: apoptosis; evasion; cancer; chromatin modifying enzymes; epigenetic drugs; therapy

\section{Introduction}

Apoptosis is a form of programmed cell death (PCD) that is observed in multicellular organisms, and it serves as a barrier to suppress cancer development [1]. Apoptosis is essential to maintain tissue homeostasis through elimination of damaged, infected, or aged cells. The decision to undergo apoptosis is made on the basis of the cells' interpretation of environmental stimuli or their self-assessment of cellular damage. When induced to undergo apoptosis, cells exhibit specific structural changes characterized by membrane blebbing, nuclear fragmentation, cell shrinkage, chromatin condensation, chromosomal DNA fragmentation, and formation of apoptotic bodies [2] (Figure 1).

This physiological program is tightly controlled within the cells, with many molecular players involved. It is well established that, in cancer, cells adopt mechanisms that allow them to evade apoptosis [3]. While genetic alterations are key in apoptotic evasion [4], epigenetic adaptation through silencing or activating molecular players of apoptosis also contributes to this process [5]. Most epigenetic changes are governed by the activity of chromatin-modifying enzymes that add, remove, or recognize different marks on histones and DNA [6]. In this review, we elaborate on how apoptosis signaling components are 
deregulated at epigenetic levels, particularly focusing on aberrant DNA methylation, aberrant histone methylation, and regulation by miRNAs. We also discuss the advances in cancer therapies with "Epi-drugs" that modulate the activity of chromatin-modifying enzymes and alter the expression and/or the activity of apoptotic molecules in cancer cells.

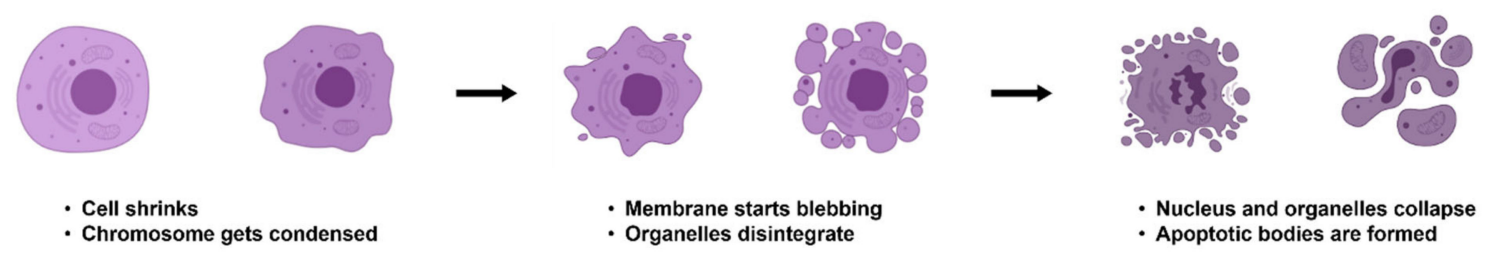

Figure 1. Morphological changes during apoptosis. Cells undergoing apoptosis start to shrink, which is followed by chromosome condensation and disintegration of organelles. Cells later collapse into apoptotic bodies that are further eliminated by the immune system. Figure generated at Biorender.com accessed on 20 April 2021.

\section{Mechanisms of Apoptosis}

Apoptosis can be triggered in response to several external stimuli such as chemicals or radiation, leading to excessive intracellular stress and DNA damage [7]. It is a very tightly regulated process governed by the activity of dozens of proteins, the most significant of which are caspases (cysteine-aspartic proteases), responsible for proteolytic degradation of cellular components. Apoptotic caspases are subcategorized as initiators (caspase-2, $-8,-9,-10)$ and executioners (caspase-3, $-6,-7)$. Once activated by the initial apoptotic signal, initiator caspases cleave and activate executioner caspases, which degrade cellular components and cause apoptosis-related changes in cellular morphology [8].

Depending on the source of the apoptotic stimuli, either the intrinsic or the extrinsic pathway of apoptosis gets activated. The intrinsic pathway is triggered by intracellular signals in response to cellular genotoxic stress inducers, such as DNA damage, defective cell cycle, loss of extracellular matrix attachment, hypoxia, or deprivation of cell survival factors. These stimuli lead to mitochondrial outer membrane permeabilization (MOMP) that initiates mitochondrial release of proapoptotic factors, such as cytochrome $\mathrm{C}$, apoptosis-inducing factor (AIF), and Smac/DIABLO from the mitochondrial intermembrane space $[9,10]$. Released cytochrome $C$ then combines with apoptotic proteaseactivating factor 1 (Apaf-1) to form the large apoptosome complex, which triggers autoactivation of caspase- -9 and consequent stimulation of effector caspases, caspase $-3,-6$, and/or -7 [11]. Smac binds and blocks the inhibitor of apoptosis proteins, IAPs (IAP-1, IAP-2, XIAP, NIAP, BRUCE, and Survivin), further promoting caspase-9 activation. Mitochondrial membrane permeability and consequent release of these factors are strictly regulated by pro- and antiapoptotic Bcl-2 family proteins [12,13]. Proapoptotic Bcl-2 family members are subdivided into two categories according to the number of $\mathrm{BH}$ (Bcl-2 homology) domains they contain (named BH1, BH2, BH3, and BH4 domains). Bax and Bak proteins possess several $\mathrm{BH}$ domains, whereas proteins such as Bid, Bad, Bim, Bmf, Puma, and Noxa have only the $\mathrm{BH} 3$ domain. These $\mathrm{BH} 3$-only proteins are responsible for activation of $\mathrm{Bax}$ and/or Bak through initiating their oligomerization and insertion into outer mitochondrial membrane, thereby allowing the permeabilization process [14]. On the other hand, antiapoptotic Bcl-2 family members, such as Bcl-2, Bcl-XL, Mcl-1, A1, and Bcl-W inhibit the Bax/Bak-mediated pore formation on mitochondria through binding and retro-translocating Bax/Bak from the mitochondria back into the cytosol [15]. That retro-translocation process is blocked by $\mathrm{BH} 3-$ only protein binding and inactivation of antiapoptotic Bcl-2 family members. Therefore, the delicate balance of the expression and activity levels of pro- and antiapoptotic Bcl-2 family proteins is extremely important for the control of apoptosis.

Proapoptotic Bcl-2 family protein expressions are tightly controlled by p53 tumor suppressor, which partially explains the potency of DNA-damaging agents to induce intrinsic apoptosis [16]. On the contrary, the extrinsic pathway gets activated by extracellular signals transmitted to the cell with the help of proapoptotic ligands of the TNF (tumor 
necrosis factor) family, such as CD95L/FasL or TRAIL/Apo2L [17], binding to their cell surface death receptors, CD95/Fas and DR4/DR5, respectively [18]. Death domains at the carboxyl terminus of ligand-bound active receptors recruit Fas-associated protein with death domain (FADD), which further recruit initiator caspases (caspase-8 or -10) through the death effector domain (DED). Consequently, death-inducing signaling complex (DISC) is formed [19], and initiator caspases are activated by autocleavage. These further activate effector caspases, caspase- $3,-6$, and/or -7 , and facilitate apoptosis through degradation of cellular components [20]. Extrinsic apoptosis can be inhibited by decoy receptors, which lack the catalytic domain necessary for proper apoptosis induction [21], as well as by c-FLIP [22]. The c-FLIP protein has a homologous sequence with caspase-8 and, thus, can compete for binding to FADD and consequently form a distinct signaling complex that activates NF- $\mathrm{KB}, \mathrm{PI} 3 \mathrm{~K}$, and MAPK signaling pathways [23]. These pathways play important roles in cell survival and proliferation and counteract the apoptotic activity. While the transduction of extrinsic or intrinsic apoptotic signals involves the activation of several proteins in a linear mode, a major crosstalk between extrinsic and intrinsic apoptosis is mediated by the protein Bid. Upon its cleavage by initiator caspase-8 [24], truncated Bid, now called "tBid", oligomerizes Bak or Bax into mitochondrial pores, changing mitochondrial membrane polarization and causing the release of cytochrome $C$ and Smac $[25,26]$. Therefore, Bid links the two apoptotic pathways (Figure 2a).

a

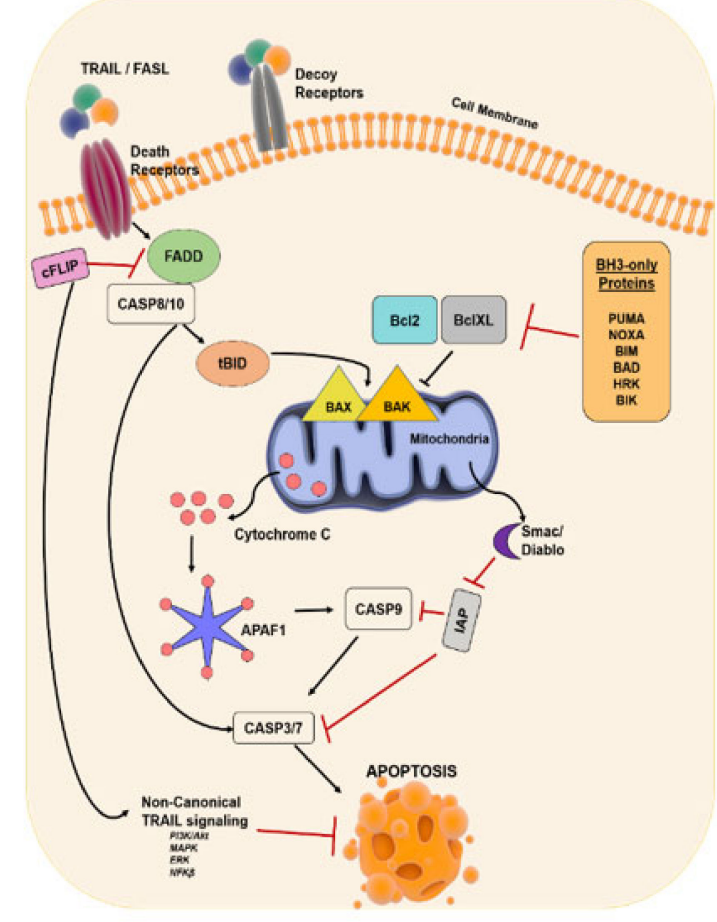

b

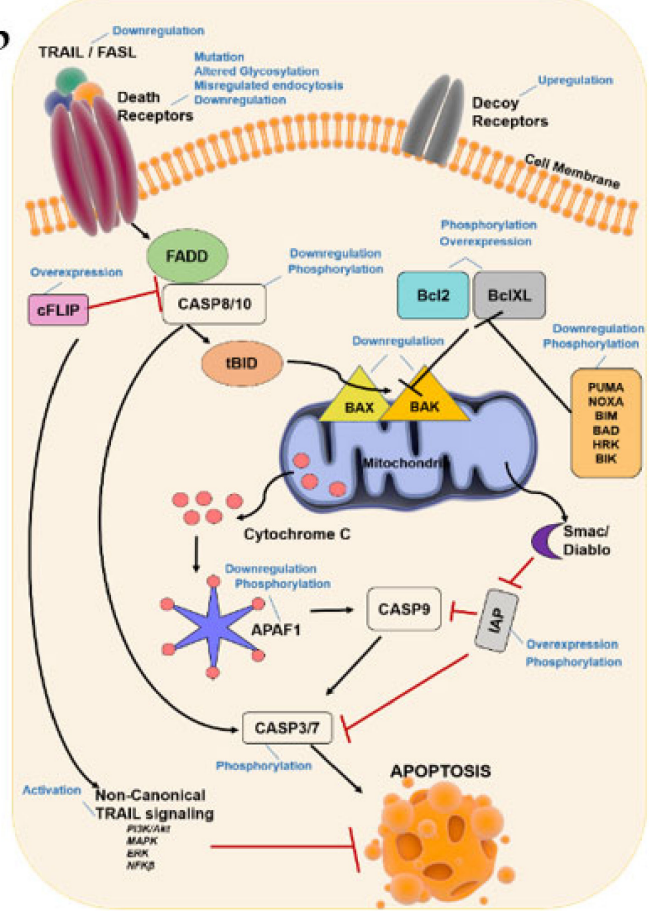

Figure 2. Extrinsic and intrinsic apoptosis and its deregulation in cancer cells. (a) Extrinsic apoptosis inducers, such as TRAIL or FasL, bind to death receptors and lead to FADD-mediated caspase- 8 activation. Active caspase- 8 cleaves and activates effector caspase-3/7 and leads to apoptosis. Caspase- 8 also truncates Bid and causes Bax and Bak oligomerization in mitochondrial outer membrane that leads to cytochrome $C$ release, consequent activation of caspase- 9 and effector caspases-3/7, and apoptosis (intrinsic). Intrinsic apoptosis can also be triggered by BH3-only proteins, which inhibit Bcl-2 and Bcl-xL antiapoptotic proteins, facilitating Bax and Bak activity. XIAP and cFLIP inhibit apoptosis through interfering with caspase activation. (b) Mechanisms of apoptosis evasion in cancer cells. The balance of pro- and antiapoptotic signal mediators is deregulated both transcriptionally (e.g., DNA hyper/hypomethylation) and post-translationally (e.g., phosphorylation) in cancer cells. Figure generated at Biorender.com accessed on 20 April 2021.

Cells are categorized as type I or II according to the type of apoptotic machinery they utilize. Type I cells rely solely on extrinsic apoptosis pathway without the involvement of 
mitochondrial signaling, since active caspase-8 produced by the DISC complex is adequate to directly activate the effector caspases and promote apoptosis [27]. On the other hand, in type II cells, both extrinsic and intrinsic pathways are utilized with the help of Bid, which amplifies effector caspase activation [28]. Most cells are known to be type II, whereas some cell types, such as mesenchymal cells, can be type I.

Although apoptosis is the most well-characterized and evolutionary conserved PCD up to date, there are several alternative mechanisms of regulated cell death, such as necroptosis, pyroptosis, and ferroptosis [29]. Pyroptosis is driven by the activation of the inflammasome, ferroptosis is iron- and lipotoxicity-dependent, and necroptosis involves kinase-mediated signaling (e.g., RIPK, MLKL) induced by extracellular (death receptor activation of death receptors or Toll-like receptors) or intracellular signals (microbial nucleic acids) [30]. Apoptosis serves as an anti-inflammatory response preserving homeostatic integrity, since intact apoptotic bodies are eliminated by resident phagocytic cells [31]. On the other hand, necroptosis and pyroptosis trigger inflammation due to the loss of plasma membrane integrity and release of intracellular contents [32,33]. The decision between apoptosis and other types of PCD mechanisms is known to involve caspase-8, which acts as a molecular switch for apoptosis, necroptosis, and pyroptosis [34]. Active caspase- 8 blocks necroptosis and pyroptosis and rather directs cells toward apoptosis. Involvement of these alternative cell death pathways in carcinogenesis is emerging as an important field, allowing better interpretation and design of new therapeutic strategies for apoptosis-resistant cancer cells. Given their yet unresolved roles in cancer, further molecular characterization of necroptosis, pyroptosis, and ferroptosis, along with their links to apoptosis, will be of utmost importance for future anticancer strategies.

\section{Hallmark of Cancer: Evasion of Apoptosis}

Apoptosis tightly regulates tumor formation, as well as response of tumor cells to currently available treatment strategies. However, most cancer cells possess an intrinsic resistance to apoptosis and find alternative strategies to evade cell death $[3,4]$.

Changes in the balance of pro- and antiapoptotic signal mediators, as well as mutations in key genes of apoptotic signaling pathway, are possible mechanisms underlying this resistance phenomenon. The balance of pro- and antiapoptotic signal mediators is regulated both transcriptionally (e.g., DNA hyper/hypomethylation) and post-translationally (e.g., phosphorylation) (Figure 2b). As an example of post-translational regulation, the activity of caspases is reduced in cancer cells through inactivation/degradation of proapoptotic Bid, Bim, Puma, Bad, Noxa, Bax, and Apaf-1 proteins by phosphorylation at distinct residues [4]. Overexpression of antiapoptotic proteins such as IAPs, Bcl-2, Bcl-XL and Akt or enhancement of their activity by phosphorylation can also contribute to apoptotic resistance in cancer cells $[4,35]$. Overexpression of cFLIP prevents clustering of FADD and caspase- 8 to form DISC and consequently results in the activation of the noncanonical TRAIL pathway. The noncanonical TRAIL pathway supports survival and proliferation of cells through activation of several signaling pathways, such as PI3K/Akt, MAPK, p38, Erk, PKC, Src, IkB/NF- $k B$, and RIP1. Furthermore, NF- $k B$ can induce the expression of genes encoding antiapoptotic proteins cFLIP, Bcl-XL, Mcl-1, and cIAP and, thus, contribute to apoptosis resistance [36]. On the other hand, silencing of cFLIP sensitizes cells to apoptosis [37]. Similarly, loss of proapoptotic Bax, Bak, and caspase-8 results in reduced sensitivity to apoptosis. Mutations, altered glycosylation, misregulated endocytosis, and reduced expression of death receptors, as well as overexpression of decoy receptors, may also confer apoptosis resistance. For example, DR5 mutations are identified in head and neck, breast, and lung cancer, and decoy receptor expression is elevated in TRAIL-resistant human osteoblasts [38].

\section{Epigenetics Mechanisms of Cancer Apoptosis Evasion}

Epigenetics involves the heritable modification [39] of histones and DNA, thereby modulating gene expression without altering the genetic code. However, epigenetic changes 
cannot be easily transmitted from one generation to the next. For transmission to occur, these epigenetic changes would have to occur in the germ cells and should escape through extensive reshaping during germ cell differentiation and the development of totipotent cells after fertilization [40]. Long-lived RNA molecules are also more likely to carry epigenetic information across generations [41], although the mechanisms remain unresolved.

DNA methylation, histone modifications, and chromatin remodeling are major epigenetic alterations that have broad effects on cell phenotype. Mammalian cells pack their long DNA (around $2 \mathrm{~m}$ long) into ordered structures, called chromatin, which are composed of nucleosomes. Nucleosomes consist of $146 \mathrm{bp}$ DNA wrapped around octamers of DNA packaging proteins, called histones. Octamers consist of two copies of each four types of core histones (H2A, H2B, H3, and H4). Linker histone $\mathrm{H} 1$ is responsible for further folding and condensation of nucleosome chains to higher-ordered structures [42].

Histone proteins are prone to a variety of post-translational modifications at their $\mathrm{N}$-terminal tails, as well as at their globular core region [43]. These modifications either modulate the affinity of histones for DNA or form new binding sites for protein modules, leading to euchromatin (relaxed, actively transcribed) or heterochromatin (condensed, inactive) formation. Phosphorylation of serine or threonine, acetylation of lysine, methylation of lysine or arginine, ubiquitination of lysine, SUMOylation, carbonylation, ADP-ribosylation, and citrulation are major post-translational modifications of histones that occur dynamically [44]. These modifications (marks) are added or removed by unique chromatin-remodeling proteins, as illustrated in Figure 3. Histone-modifying enzymes that add these post-translational marks are named "writers", enzymes that remove these modifications are called "erasers", and proteins that recognize these marks for further regulation are called "readers" [6]. DNA methyltransferases (DNMT), histone methyltransferases (HMT), and histone acetyltransferases (HAT) are the most common writer proteins, whereas histone demethylase (HDM) and histone deacetylases (HDAC) are common erasers. Histone methylation can be associated with both transcriptional repression (e.g., H3K27me3, H3K9me2 and H3K9me3, and H4K2Ome3) and activation (e.g., H3K4me3) depending on the position of the methyl group and methylation level. However, histone acetylation (e.g., H3K9ac, H4K5ac, H4K8ac, H4K12ac, and H4K16ac) leads to a euchromatin state. Post-translational modifications are recognized and further processed by various domains of epigenetic readers (namely, Bromo, Chromo, PHD, Tudor, MBT, BRCT, and PWWP domains) to regulate cellular processes, such as gene transcription, DNA repair, replication, and chromosome condensation [45].

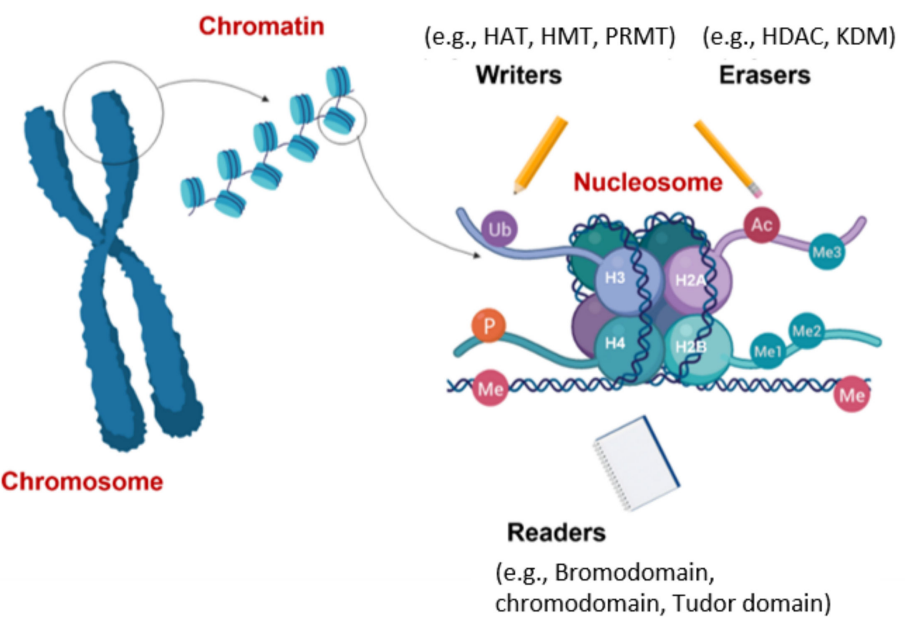

Figure 3. Subgroups of chromatin modifier proteins: writers, erasers, and readers. Posttranslational marks are added by "writers", recognized and further processed by "readers", and removed by "erasers". Figure generated at Biorender.com accessed on 20 April 2021. 
Chromatin remodeling is another epigenetic alteration conducted by remodeling complexes called SWI2/SNF2, which physically modulate nucleosomes through octamer sliding, DNA looping [46-48], and histone substitution [49] to induce transcription of various genes, as summarized in Figure 4. Octamer sliding and DNA looping modulate the transcriptome by changing the accessible surface area of the nucleosome. The replacement of histones with their variants has distinct consequences depending on the variant type. Variants H3.3 and H2ABbd are associated with transcription activation. Replacement of H3.3 by remodeling complexes results in the immediate activation of genes previously silenced by histone H3 lysine 9 methylation [50]. On the other hand, MacroH2A and H2A.X variants repress transcription through inhibiting the binding of transcription factors. Replacement of the histone $\mathrm{H} 2 \mathrm{~A}$ with its variant H2A.Z is important for the regulation of gene expression both positively and negatively through changing the accessible surface of the nucleosome [51].
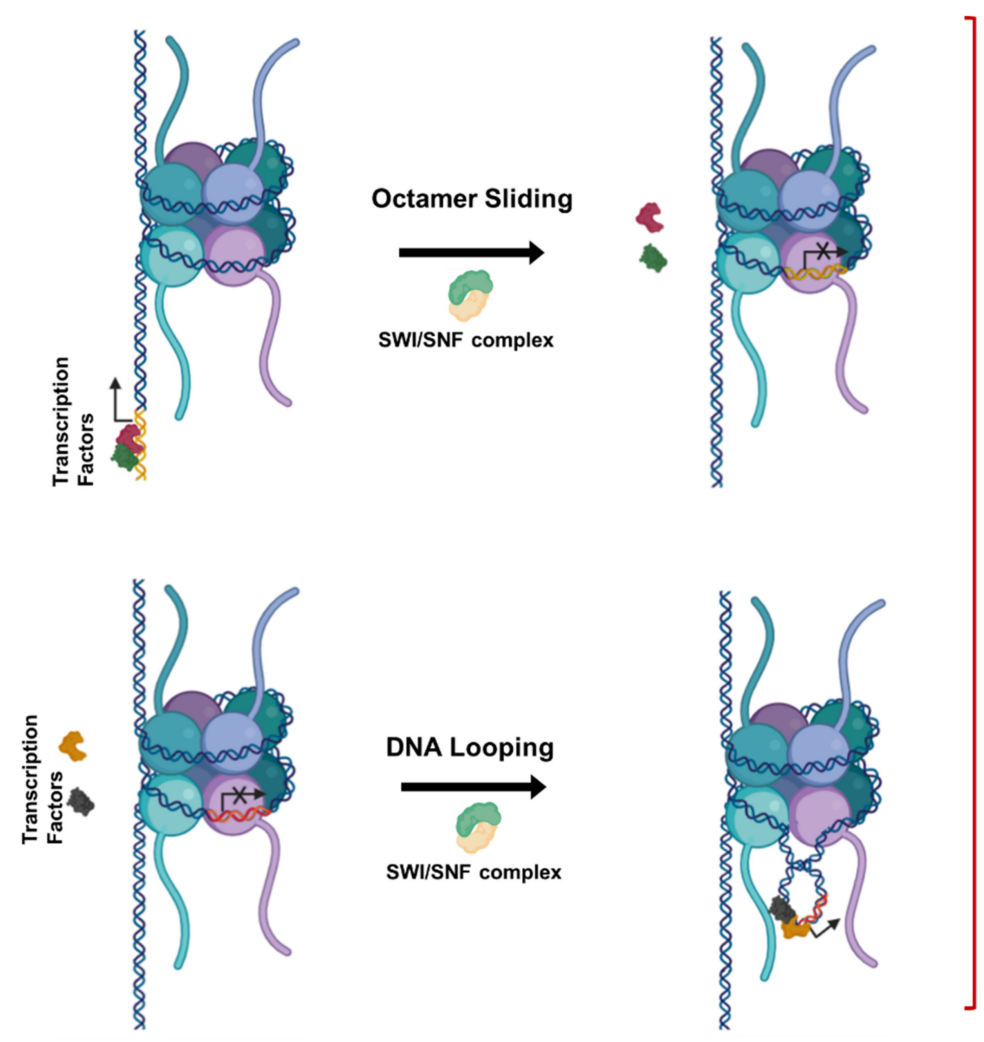

Changes the accessible surface of the nucleosomal DNA to transcription factors
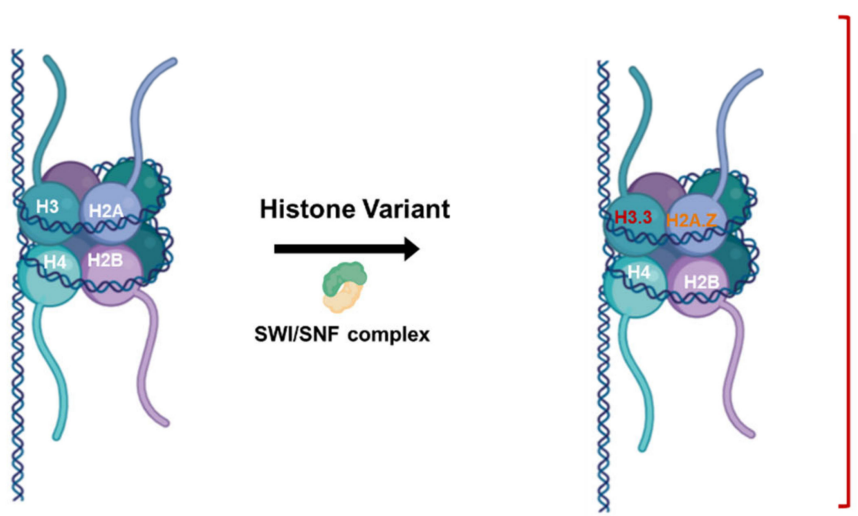

H3.3: Activation MacroH2A:Repression H2AZ: Activation / Repression H2A.X:Repression H2ABbd: Activation

Figure 4. Epigenetic modulation of gene expression through chromatin remodeling. Octamer sliding and DNA looping change the accessible surface area of nucleosomal DNA and regulate the access of transcription factors. Histone variants have distinct functions that could activate or repress gene expression in a context-dependent manner. Figure generated at Biorender.com accessed on 20 April 2021. 
Modifications of histones modulate the capacity of genome to store and inherit genetic information and significantly differ among healthy versus tumor cells. In addition to genetic abnormalities, epigenetic alterations have major roles in initiation and progression of tumors, as well as their drug resistance. Abnormal DNA methylation and distinct histone modification patterns due to aberrant activity of epigenetic modifiers are very common in tumor cells and have effects on drug response and tumor growth $[5,52]$.

Epigenetic functional classification divides cancer genes into epigenetic modifiers, mediators, and modulators. Epigenetic modifiers (e.g., Smarca4, PBRM1, ARID1A, ARID2, ARID1B, DNMT3A, TET2, MLL1/2/3, NSD1/2, SETD2, EZH2, and BRD4) modify the epigenome directly through DNA methylation, the post-translational modification of histones, or the alteration of the structure of chromatin, and they are frequently subjected to mutations in cancer. Emerging evidence for the role of DNMTs in malignant transformation and contribution of DNMT overexpression, mutation, and deletion to tumorigenesis was previously summarized by Zhang et al. [53]. In addition to DNA methylation, mutations in histone lysine methyltransferases SETD2 and MLL2 are frequently observed in enteropathyassociated T-cell lymphoma (93\%) and follicular lymphomas (89\%), acting as a driver of carcinogenesis $[54,55]$. SETD2-inactivating mutations are associated with poor outcome and disease relapse in renal cell carcinoma [56] and pediatric acute lymphoblastic leukemia [57]. Another HMT responsible for H3K27 methylation, EZH2, is bifunctional as either tumorsuppressing or tumor-promoting depending on the cancer type. EZH2 is subjected to gainof-function mutations and is overexpressed in various solid tumors (breast, ovarian, lung, liver, bladder, glioblastoma), whereas it is inactivated through deletions and frameshift, nonsense, and missense mutations in myeloproliferative neoplasms (MPNs) and in human T-cell acute lymphoblastic leukemia [58]. Histone acetylation is as important as methylation for initiation of carcinogenesis. Mutations and translocations in HAT family members (p300, CBP, and MYSTA4) have been observed in both hematological malignancies and solid tumors. In line with this evidence, massive loss of histone acetylation through germline mutations and overexpression of HDACs silence tumor suppressor genes in various tumor types [59]. Mutations in enhancers or transcription factor-binding sites, which prevent the binding of chromatin regulators, are also drivers of oncogenesis and can be classified as epigenetic modifiers. DNA and histone demethylation also contribute to the resistance to apoptosis. K370me2 demethylation by KDM1A suppresses the apoptosis initiator function of p53 by blocking its interaction with 53BP1 [60]. In line with this evidence, KDM1A inhibitor, HCI-2509, triggered apoptosis in Ewing sarcoma cell lines, endometrial carcinoma, and AML cells as a single agent, as well as in combination with anticancer drugs [61-63]. Another potent KDM1A inhibitor, GSK2879552, is under Phase I clinical trial (NCT02177812) for patients with relapsed/refractory AML. KDM3A was illustrated to facilitate tumor growth [64], modulate invasion and apoptosis of breast tumor cells by targeting histones and p53 [65], and sustain myeloma cell survival [66]. Another member of the KDM family, KDM6B, has context-dependent function in tumorigenesis. KDM6B elevates the expression of antiapoptotic protein Bcl-2 in an ER $\alpha$-dependent fashion in breast tumors [67]. Oppositely, KDM6B prevents carcinogenesis by stabilizing nuclear p53 and results in partial cell-cycle arrest and differentiation in germline stem cells [68]. TET family DNA demethylases also modulate the apoptotic response of tumor cells. TET2 mutations affect non-CpG island DNA methylation at enhancers and transcription factor-binding sites in chronic myelomonocytic leukemia [69]. TET1 expression regulates proliferation and apoptosis in osteosarcoma cells [70]. Vitamin C promotes apoptosis in breast cancer cells by increasing TRAIL expression through TET-dependent DNA demethylation [71].

On the other hand, epigenetic mediators (OCT4, NANOG, LIN28, SOX2, and KLF4) are targets of epigenetic modifications and are responsible for the emergence of cancer stem cells (CSCs). ncRNAs are also epigenetic mediators associated with carcinogenesis. Misregulation of ncRNA expression through amplifications, deletions, mutations, and epigenetic modulation is also associated with tumorigenesis. DNA methylation-mediated silencing of miR-34b/c, miR-148, and miR-93 results in aberrant activity of oncogenic 
C-MYC, E2F3, CDK6, and TGIF2 and promotes invasiveness and metastasis of tumor cells [72]. Lastly, epigenetic modulators (IDH1/2, KRAS, APC, TP53, STAT1/3, YAP1, and CTCF) lie upstream of the modifiers and mediators in signaling. These modulators relay signals from environmental stress, injury, inflammation, and aging to modifiers to epigenetically alter tumor suppressors or oncogenes [73]. Heterozygous somatic mutations in IDH1/2 are evident in $20 \%$ of AMLs and are linked to global hypermethylation, as well as gene-specific methylation signatures [74].

Several epigenetic mechanisms are misregulated in cancer cells, and epigenetic regulation of apoptosis can be categorized into three major themes as summarized below: evading apoptosis (1) by aberrant DNA methylation, (2) by aberrant histone modifications, and (3) by epigenetic regulation of miRNAs.

\subsection{Evading Apoptosis by Aberrant DNA Methylation}

Regions in DNA where a C nucleotide is followed by a G nucleotide in the $5^{\prime} \rightarrow 3^{\prime}$ direction are called CpG sites. CpG nucleotide-rich regions (300-3000 bp) in mammalian genomes are called $\mathrm{CpG}$ islands, and these islands reside in very close proximity to gene promoters [75]. The methyl residue is transferred from a methyl donor SAM (Sadenosyl-L-methionine) to the $5^{\prime}$ carbon of cytosine in CpG sites by enzymes called DNA methyltransferases (DNMTs). DNMT1 functions as a 'maintenance' methyltransferase and is responsible for copying DNA methylation during cell division, while DNMT3A and DNMT3B are de novo methyltransferases, which do not require a methylated template [76,77]. The methyl motif attracts specific methyl-DNA-binding proteins (e.g., MeCP2, MBD1, MBD2, MBD3, MBD4, and KAISO) and blocks the access of transcription factors (e.g., AP-2, c-Myc/Myn, CREB, E2F, and NF- $\mathrm{BB}$ ) to $\mathrm{CpG}$ sites, resulting in transcriptional silencing, as illustrated in Figure 5 [78]. Therefore, $\mathrm{CpG}$ island methylations at promoter sites are tightly regulated.

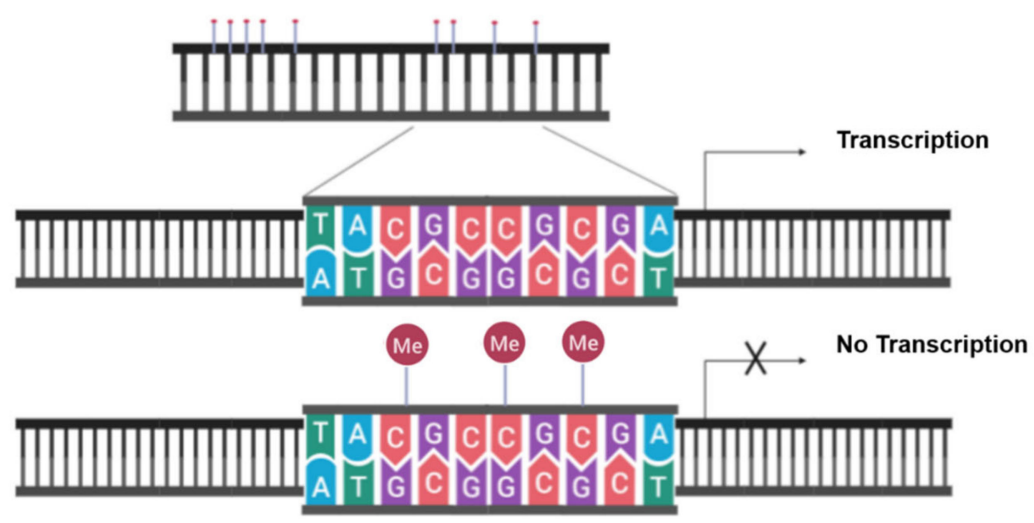

Figure 5. CpG island methylation blocks transcription. Methylation blocks the access of transcription factors to $\mathrm{CpG}$ sites and, therefore, results in transcriptional silencing. Figure generated at Biorender.com accessed on 20 April 2021.

CpG islands at tumor suppressor and proapoptotic gene promoters are mostly hypermethylated in cancer cells due to DNMT overexpression [79] or gene mutations (e.g., IDH1 [80], SDH [81], TET2 [69]), which lead to uncontrolled division and growth of cells [82]. Hypermethylation blocks the initiation and progression of both intrinsic and extrinsic apoptosis by modulating the expression of major players of cell death cascade, as previously reviewed by Elmallah and Micheau [83]. Promoter hypermethylation-mediated silencing of FAS expression renders colonic epithelium cells resistant to apoptosis and contributes to neoplastic transformation into cutaneous T-cell lymphoma [84] or colon carcinoma [85]. Similarly, DR4 and DR5 promoter methylation results in resistance to TRAIL-induced apoptosis in human neuroblastoma [86], melanoma [87], and ovarian cancer [88]. Caspase-8/10 silencing by promoter methylation disrupts the cycle of apop- 
tosis in hepatocellular carcinoma [89], bladder cancer [90], small-cell lung carcinoma [91], glioblastoma [92], retinoblastoma, and neuroblastoma [93]. In renal cell carcinoma and chronic myeloid leukemia, silencing of BIM by promoter hypermethylation confers resistance to potent apoptosis induction [94]. APAF-1 silencing is evident in leukemia [95] and melanoma [96], as well as gastric [97], bladder, and kidney cancer [98], and it is correlated with therapy resistance. In gastric and bladder cancer, XAF1, an inhibitor of antiapoptotic XIAP, is downregulated by promoter hypermethylation, and this is correlated with pathology and clinical outcome [99-101]. BCL-2 promoter is hypermethylated in prostate cancer [102]. Proapoptotic BAX, BAK and PUMA genes are also subject to promoter hypermethylation-mediated silencing in multiple myeloma cells [103] and Burkitt's lymphoma [104]. Proapoptotic BAD promoter is hypermethylated in myeloma [103]. $B C L-$ 2L10 hypermethylation is observed in gastric cancer [105] and leukemia [106]. BIK is downregulated by hypermethylation in glioma [107], RCC [108], prostate cancer [109], and myeloma [110]. BNIP3 levels are modulated through methylation for gastric cancer [111], colorectal cancer [112], leukemia [113], and HCC [114]. Proapoptotic HRK hypermethylation is evident in colorectal, gastric [115], glioblastoma [116], PCNSL [117], and prostate cancer [118].

Other critical genes affected by hypermethylation are $p 16^{I N K 4 a}$, a cell-cycle inhibitor; $A P C$, a cell cycle regulator; and MGMT, BRCA1, and MLH1, DNA repair genes [119]. Silencing of the MGMT gene by promoter hypermethylation predicts patient response to temozolomide treatment and is associated with better prognosis in glioma [120]. Tumor suppressor DAPK (death-associated protein kinase) was previously shown to be silenced by promoter hypermethylation in colorectal [121] and lung cancers [122] and B-cell lymphoma [123], which renders cancer cells less responsive to TNF-induced apoptosis. HIC1 (hypermethylated in cancer 1) gene expression is found in various cancers to be silenced by DNA hypermethylation $[124,125]$. The loss of HIC1 results in inactivation of p53, allowing cells to bypass apoptosis and survive DNA damage. The TP53 gene itself is also subjected to hypermethylation in acute lymphatic leukemia patients [126]. RASSF1, a tumor suppressor gene, is also hypermethylated in several human tumors, such as parathyroid tumors [127], nasopharyngeal carcinoma [128], non-small-cell lung cancer [129], and hepatoblastoma [130].

In addition to gene silencing, CpG island methylation can cause destabilizing of genetic mutations and consequent tumorigenesis due to the favorable conversion to thymine by hydrolysis of the amine group. CpG islands are sites to $\sim 35 \%$ of all point mutations in the germline [131] and important hotspots for acquired somatic mutations leading to cancer $[132,133]$. In addition, cytosine methylations modulate the UV light absorption level of the nucleotide base, creating pyrimidine dimers [134].

In addition to aberrant hypermethylation, cancer cells possess global genomic hypomethylation, which contributes to their highly proliferative and apoptosis resistant phenotype. Cancer-associated DNA hypomethylation in the human genome was discovered in 1983 [135,136]; yet, at the time, the biological significance of this finding was not clearly understood. Global genomic hypomethylation is evident in various types of human cancer, including prostate metastatic tumors [137], B-cell chronic lymphocytic leukemia [138], hepatocellular carcinomas [139], and cervical cancer [140], as well as colorectal cancer, gastric cancer, and melanomas [5]. Heterochromatin repeats (e.g., satellite DNA, endogenous retrotransposons) are shown to be hypomethylated in various cancer types, and such a pattern could affect chromatin structure and genomic stability, in addition to possible effects on transcription of other parts of the genome. Hypomethylation can lead to chromosome instability through translocations and deletions due to loosening of chromatin structure, reactivation of transposable elements, and mitotic recombination [141]. Interspersed repeat (e.g., retrotransposon LINE-1) hypomethylation is observed in chronic lymphocytic leukemia [142], urinary bladder carcinomas [143], hepatocellular carcinomas [144], and prostate carcinomas [145]. Oncogene promoters and some gene regulatory sequences are mostly hypomethylated in cancer cells [146]. Cancer-associated hypomethylation occurs 
also in several tumor-initiator or proliferation-associated genes, such as pS2gene [147], HOX11 proto-oncogene [148], and c-MYC and $c-N$-ras oncogenes [149,150]. Contribution of aberrant DNA methylation to apoptosis resistance is summarized in Figure 6.

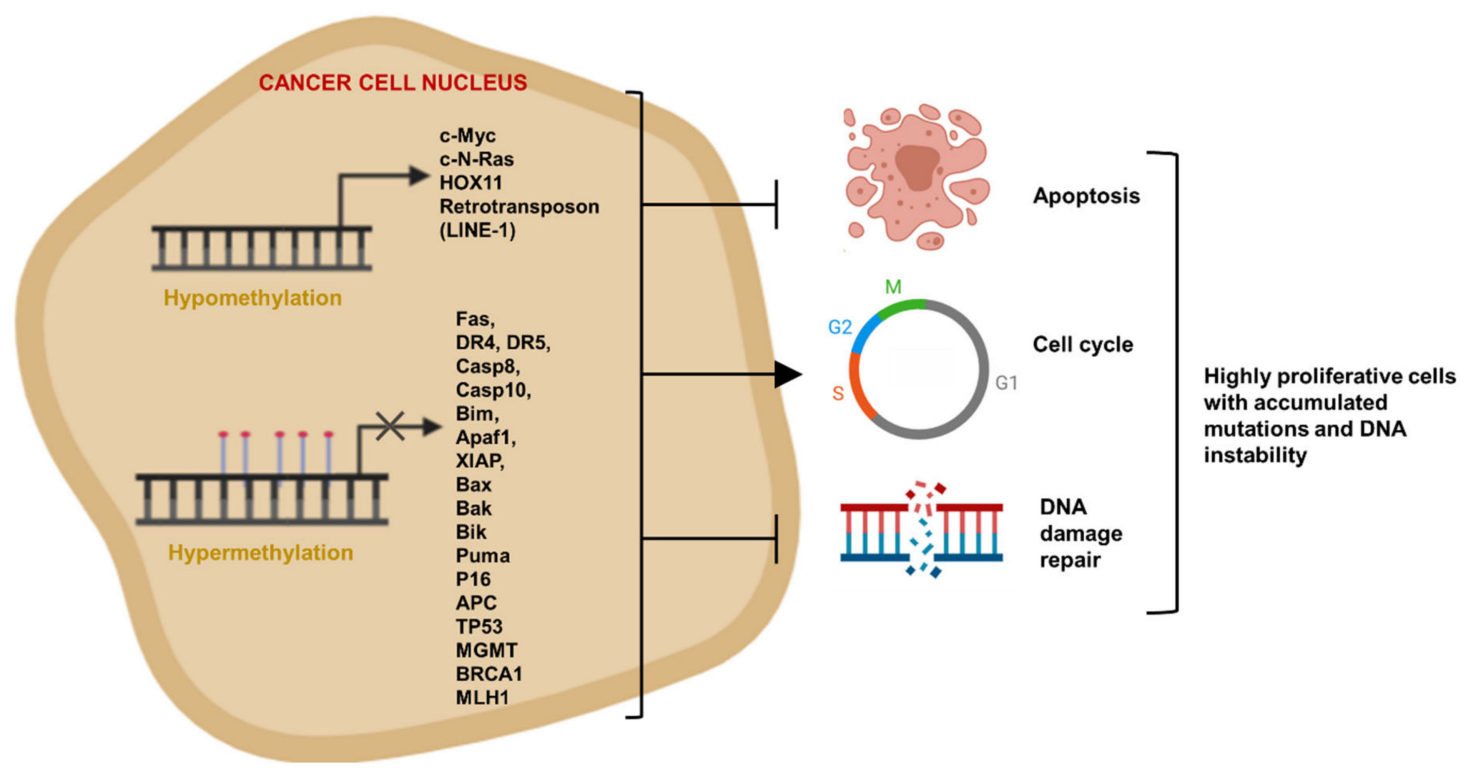

Figure 6. Evasion of apoptosis by DNA hypermethylation and global hypomethylation. CpG islands at promoters of tumor suppressor, proapoptotic, cell-cycle regulator, and DNA damage repair genes are mostly hypermethylated in cancer cells due to DNMT overexpression or gene mutations, which lead to uncontrolled division and growth of cells. Cancerassociated hypomethylation occurs in several tumor-initiator or proliferation-associated genes and leads to chromosome instability. Figure generated at Biorender.com accessed on 20 April 2021.

\subsection{Evasion of Apoptosis by Aberrant Histone Modifications}

CpG island hypermethylation commonly observed in cancer cells is interconnected with histone marks, such as elevated $\mathrm{H} 3 \mathrm{~K} 9$ me and H3K27me3 levels, as well as $\mathrm{H} 3$ and H4 deacetylation and loss of H3K4me3 [151-153]. The relationship between DNA methylation and histone modifications is established with the help of methyl-DNA binding proteins, such as MeCP2, MBD1, and Kaiso [154]. These proteins interact with methylated CpG islands and recruit histone deacetylases (HDACs, Sirtuins) and histone methyltransferase complexes to the site. Similarly, the histone code can further determine DNA methylation patterns by recruiting methyltransferase enzymes. For instance, histone methyltransferase G9a recruits DNA methyltransferases, DNMT3A and DNMT3b, to promoter sites [155].

Aberrant histone modifications are among hallmarks of cancer. Some of the histone marks related to tumorigenesis are reduced acetylation of $\mathrm{H} 3$ and $\mathrm{H} 4$ due to high HDAC or low HAT activity, decreased H3K4me3 mark, and increased H3K9me3 and H3K27me3 modifications, which can silence tumor suppressor genes or proapoptotic genes to facilitate uncontrolled growth of cells. Deprivation of H4K16ac and H4K20me3 has been suggested to be a prevalent hallmark of cancer cells due to their contribution to chromosome instability [156]. Phosphorylation of histone H2A, H2B, H3, and H4, dephosphorylation of histone $\mathrm{H} 1$, and deubiquitylation of histone $\mathrm{H} 2 \mathrm{~A}$ have also been linked to the apoptotic process [157]. Cancer cells adopt epigenetic mechanisms, such as increasing the H3K4me3 permissive mark to increase expression of DNA repair genes such as $B R C A 1, B R C A 2$, or $M G M T$ and consequently avoid drug toxicity [35]. Hypoxic stress-mediated epigenetic silencing of the DNA mismatch repair gene, MLH1, is established by decreased H3K4 methylation at the promoter via demethylases [158]. Other apoptosis-related genes repressed by epigenetic mechanisms include $p 16^{I N K 4 a}$ [159], $p 57^{K i p 2}$ [160], GAS2, PIK3CG, and p21 ${ }^{\text {Waf }}[161]$. 
Separately, several histone modifications are involved in chromatin alterations such as inter-nucleosomal DNA fragmentation, chromatin condensation, and increased chromatin accessibility, which are all related to apoptosis. To this end, protein complexes governing cell death and survival decisions might be recruited by specific epigenetic histone marks. For instance, H2A.X-Y142 phosphorylation inhibits MDC1-mediated binding of DNA repair factors (MRE11, RAD50, NBS1, 53BP1, and BRCA1) to H2A.X-S139ph $(\gamma$-H2A.X) sites, instead facilitating the recruitment of proapoptotic components, thus modulating cell fate after DNA damage induction [162,163]. The H2B-S14ph mark has been linked to chromatin condensation [164] and inter-nucleosomal DNA fragmentation [165], in addition to its contribution to the inhibition of survival related genes, such as NF- $\kappa B$ [166]. Similarly, PKC $\delta$-mediated phosphorylation of H3T45 induces structural changes within the nucleosome and augments DNA fragmentation during late apoptosis [167]. Therefore, harmonious coordination of a wide variety of histone marks is critical for the determination of cell fate.

In addition to histone marks, histone variants by themselves can contribute to tumorigenesis. For example, high levels of histone variant H2A.Z are evident in several cancer types, such as hepatocellular carcinoma and bladder cancer. This contributes to proliferation and genomic instability and reshaping of the chromatin structure so that new genes get activated through recruitment of transcription machinery [168]. H2A.Z knockdown was shown to downregulate $B C L-2$ and upregulate BAK, CASPASE-3, and CASPASE-9 in in intrahepatic cholangiocarcinoma [169]. Components of the apoptosis pathway can also be subjected to direct regulation by aberrant histone modifications. DR4 gene expression is modulated by aberrant $\mathrm{H} 3$ and $\mathrm{H} 4$ acetylation patterns at the promoter site in medulloblastoma patients [170]. Similarly, abnormal $\mathrm{H} 3$ and $\mathrm{H} 4$ acetylation patterns modulate proapoptotic Bax protein levels [171]. The H3K27me3 repressive mark modulates proapoptotic BIM levels in Burkitt's lymphoma [172].

In addition to their roles in gene regulation through histone modifications, HATs and HDACs can contribute to tumorigenesis by modifying non-histone proteins such as $\mathrm{Rb}$, E2F, p53, ku70, and TFIIF [173]. For example, acetylation-dependent stabilization elevates E2F1-mediated apoptosis upon genotoxic stress [174]. Another example is the regulation of $\mathrm{Ku} 70$, whose expression is induced upon DNA damage playing a critical role in apoptosis regulation. Ku70 normally interferes with Bax activation through blocking its translocation to mitochondrial membrane and inhibiting apoptosis. Two important lysine residues of Ku70 (lysines 539 and 542) are acetylated by CBP and PCAF, which disrupts the Ku70-Bax interaction and, thus, facilitates apoptosis [175].

Aberrant histone modifications and their contribution to evasion of apoptosis are summarized in Figure 7.

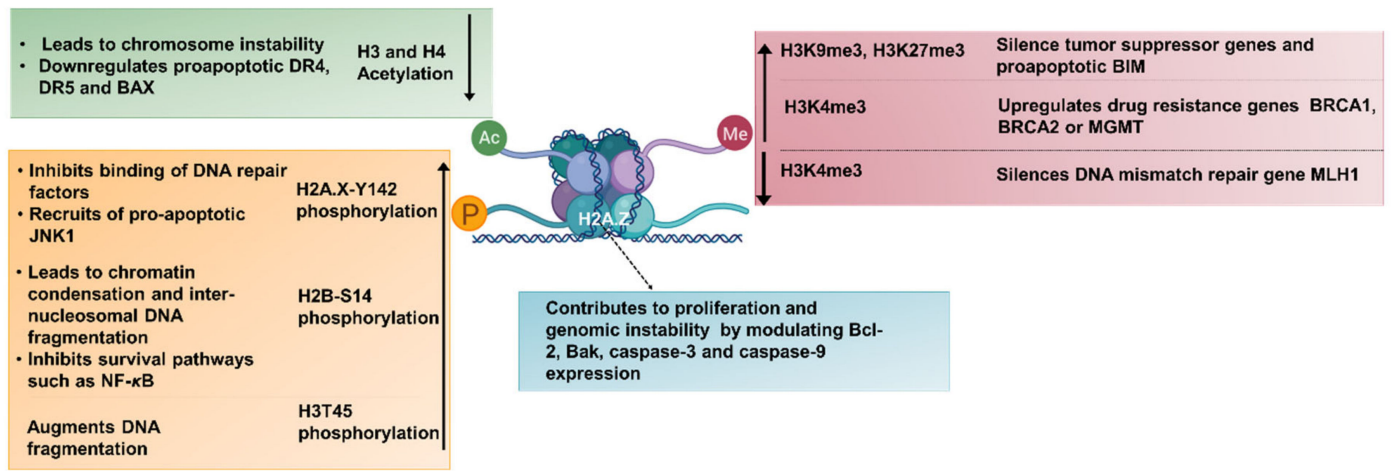

Figure 7. Aberrant histone modifications and their contribution to evasion of apoptosis. Histone marks related to Table 3. and H4 due to high HDAC or low HAT activity, decreased H3K4me3 mark, and increased H3K9me3 and H3K27me3 modifications, which can silence tumor suppressor genes or proapoptotic genes to facilitate uncontrolled proliferation of cells. Histone phosphorylation and incorporation of histone variants also contribute to tumorigenesis by promoting proliferation and genomic instability. Figure generated at Biorender.com accessed on 20 April 2021. 


\subsection{Evading Apoptosis by Epigenetic Regulation of miRNAs}

Aberrant DNA methylations and histone modifications also affect microRNA (miRNA) expression in cancer cells. miRNAs are small noncoding RNAs endogenously expressed in the cells; they are responsible for the regulation of gene expression and have broad effects on proliferation, differentiation, and apoptosis [176]. As illustrated in Figure 8, miRNA generation is a multistep process. It starts in the nucleus through RNA polymerase II-mediated synthesis of hairpin-structured primary miRNAs (pri-miRNAs), which are further processed by nuclear endonuclease Drosha into $70 \mathrm{nt}$ long precursor miRNAs (pre-miRNAs). Pre-miRNAs are transported to the cytoplasm by Exportin- 5 through the nuclear pore complex and get cleaved in the cytoplasm by Dicer into mature 21-23 nt long miRNA duplexes. Upon separation of the duplex, the guide strand gets loaded into the RISC complex and scans the transcriptome for complementary sites. Upon binding to complementary mRNA, RISC initiates either mRNA degradation or translation repression to control gene expression [177].

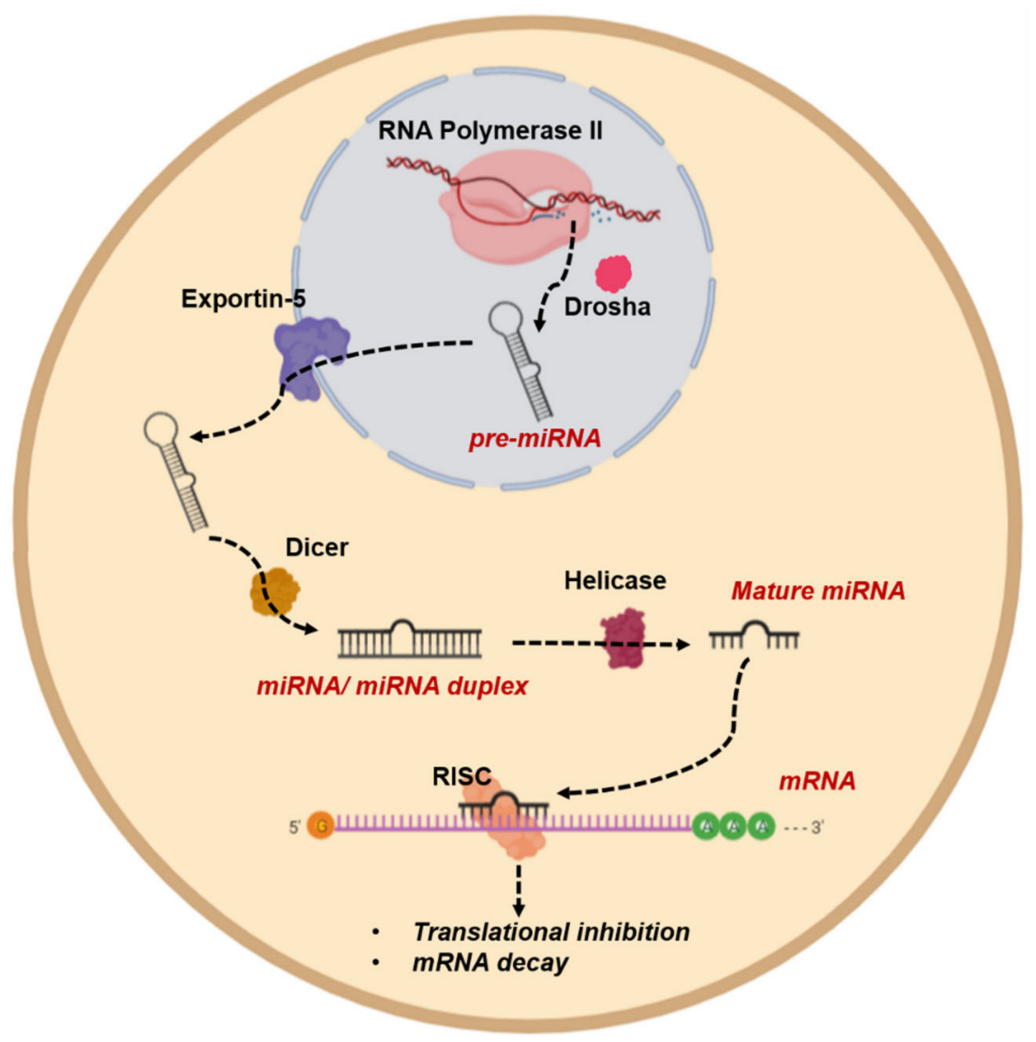

Figure 8. miRNA generation and action in the cell. miRNAs are small noncoding RNAs endogenously expressed in the cell and generated through a multistep process. RNA polymerase II synthe Table 5. pre-miRNAs are transported to the cytoplasm and get cleaved in the cytoplasm by Dicer into mature miRNA duplexes. Upon separation of the duplex, the guide strand gets loaded into the RISC complex and scans the transcriptome for complementary sites. Upon binding to complementary mRNA, RISC initiates either mRNA degradation or translation repression to control gene expression. Figure generated at Biorender.com accessed on 20 April 2021.

Some miRNAs with critical gene targets involved in apoptosis can be modulated by aberrant DNA and histone modifications in cancer cells. Some examples are described below. miR15/16 miRNAs silence antiapoptotic BCL-2, as well as CYCLIND1, MCL1, and WNT3A at the post-transcriptional level $[178,179]$. In several human malignancies such as pituitary adenoma [180] and B-cell chronic lymphocyte leukemia [181], downregulation of the miR-15/16 cluster is evident. The miR $15 / 16$ cluster is epigenetically silenced by histone deacetylation [181]. Indeed, the Myc protein represses miR-15a/16-1 cluster expression 
through recruitment of HDAC3 in mantle cell lymphoma [182]. Another example is the miR-34 family, which can be directly induced by p53 and can target CYCLINE2, MET, $M Y C N$, NOTCH1/2, CDK4/6, and antiapoptotic BCL-2 [183]. Similarly, miR-34 is repressed via hypermethylation in human gastric cancer, chronic lymphocytic leukemia, pancreatic, breast, colon, and kidney cancer, and Burkitt's lymphoma [184,185]. Another example is miR-29b, which targets DNMT3b [186] and MCL1 and is remarkably downregulated in lung [187], prostate [188], bladder [189], and ovarian cancers [190], as well as glioblastomas [191]. miR-193a-3p, miR-512-5p, miR-153, and miR-133B also target MCL1 and are repressed via hypermethylation in AML [192], gastric tumors [193], glioblastoma [194], and lung cancer [195], respectively. DNMT inhibitor 5-aza-2'-deoxycytidine and HDAC inhibitor 4-phenylbutyric acid can restore the expression of the silenced miR-512-5p in human gastric cancer cells [193], attesting to its epigenetic regulation. Similarly, miR-127 that directly targets proto-oncogene BCL-6 [196] is hypermethylated in bladder, prostate, breast, and lung cancer, as well as lymphoma [197]. Two other examples are miR-106b and miR-93, which are known to impair TGF $\beta$-induced apoptosis through inhibition of BIM expression in gastric cancer cells [198]. miR-106b and miR-93 are intronic miRNAs, and their transcription is modulated by the $\mathrm{CpG}$ islands located in the promoter of the host gene MCM7. SAHA, an HDAC inhibitor, can repress their expression by repressing MCM7 in hepatocellular carcinoma cells [199].

There are several other cancer-associated miRNAs whose expression modulation is not very well understood from the epigenetics aspect. For example, the miR-221 and miR-222 cluster targets several genes including PTEN, TIMP3, $p 27^{\text {Kip } 1}, p 57^{\text {Kip } 2}$, DDIT4, FOXO3A [200], and proapoptotic PUMA [201] and CASPASE-3 [202], and it is upregulated in multiple solid tumors such as bladder cancer [203] and glioma [204]. The miR-17-92 cluster and its paralog miR-106b-93-25 cluster target $p 21^{\text {Cip1 }}$ and proapoptotic BIM [205], and they are known to be overexpressed in multiple solid tumors, including lung and colon cancer, lymphoma, medulloblastoma, and multiple myeloma [206,207]. miR-135a inhibits $J A K 2$ and results in consequent downregulation of antiapoptotic Bcl-xL [208,209]. miR-135a is downregulated in classic Hodgkin lymphoma, AML [210], and ovarian cancer [211]. miR491 also targets $B C L-x L$ in colorectal cancer [212]. Egr2 is a tumor-suppressive transcription factor, which induces apoptosis through Bnip3L and Bak activation [213]. miR-150 targets EGR2 to promote gastric cancer progression [214]. Macrophage migration inhibitory factor (MIF) triggers apoptosis in gastric epithelial cells through repressing p53 phosphorylation and upregulating BCL-2 expression [215]. miR-451 targets MIF and is downregulated in gastric cancer [216]. Epstein-Barr virus (EBV) is the first human virus discovered to express miRNA called miR-BART5 [217], which is associated with gastric cancer [218]. miR-BART5 renders gastric cancer cells resistant to apoptosis by targeting PUMA [219]. PTEN is a tumor suppressor that facilitates apoptosis through negatively regulating the PI3K/Akt survival pathway [220]. PTEN is targeted by miR-21 [221], whose expression is elevated in gastric cancer tissues. miR-375 also modulates the activity of PI3K/Akt pathway through direct targeting of $P D K 1$ and is downregulated in gastric cancer [222]. NF- $\mathrm{KB}$ signaling is also inhibitor of apoptosis [223] and is directly targeted by miR-9, which is downregulated in gastric cancer.

Epigenetic strategies of apoptosis evasion adopted by tumor cells are summarized in Tables $1-3$ by extending previous the review of Hajji and Joseph [78]. 
Table 1. Epigenetic modification of the core apoptotic machinery.

\begin{tabular}{|c|c|c|c|}
\hline Pro/Antiapoptotic Genes & Epigenetic Modification & Outcome & Cancer Type \\
\hline FAS & DNA hypermethylation & Downregulation & T-cell lymphoma [84], colon carcinoma [85] \\
\hline \multirow{2}{*}{$D R 4 / D R 5$} & DNA hypermethylation & Downregulation & $\begin{array}{l}\text { Neuroblastoma [86], melanoma [87] and } \\
\text { ovarian cancer [88], }\end{array}$ \\
\hline & $\mathrm{H} 3$ and $\mathrm{H} 4$ deacetylation & Downregulation & Medulloblastoma [170] \\
\hline CASPASE-8/10 & DNA hypermethylation & Downregulation & $\begin{array}{c}\text { Hepatocellular carcinoma [89], bladder } \\
\text { cancer [90], small-cell lung carcinoma [91], } \\
\text { GBM [92], retinoblastoma, and } \\
\text { neuroblastoma [93] }\end{array}$ \\
\hline \multirow[t]{2}{*}{$B I M$} & DNA hypermethylation & Downregulation & $\begin{array}{c}\text { Renal cell carcinoma and chronic myeloid } \\
\text { leukemia [94] }\end{array}$ \\
\hline & H3K27me3 repressive mark & Downregulation & Burkitt's lymphoma [172] \\
\hline$A P A F-1$ & DNA hypermethylation & Downregulation & $\begin{array}{c}\text { Leukemia [95], melanoma [96], and gastric } \\
\text { [97], bladder, and kidney cancer [98] }\end{array}$ \\
\hline$X A F 1$ & DNA hypermethylation & Downregulation & Gastric and bladder cancer [99-101] \\
\hline \multirow{3}{*}{$B C L-2$} & DNA hypermethylation & Downregulation & Prostate cancer [102] \\
\hline & $\begin{array}{l}\text { miR-15/16 silencing by } \\
\text { histone deacetylation }\end{array}$ & Upregulation & $\begin{array}{c}\text { Pituitary adenoma [180] and B-cell chronic } \\
\text { lymphocyte leukemia [181] } \\
\text { Gastric cancer, chronic lymphocytic }\end{array}$ \\
\hline & miR-34 hypermethylation & Upregulation & $\begin{array}{l}\text { leukemia, pancreatic, breast, colon, and } \\
\text { kidney cancer, and Burkitt's lymphoma } \\
{[184,185]}\end{array}$ \\
\hline \multirow[t]{2}{*}{$B A X$} & DNA hypermethylation & Downregulation & $\begin{array}{c}\text { Multiple myeloma cells [103] and Burkitt's } \\
\text { lymphoma [104] }\end{array}$ \\
\hline & $\mathrm{H} 3$ and $\mathrm{H} 4$ deacetylation & Downregulation & Colon cancer [171] \\
\hline$B A K$ & DNA hypermethylation & Downregulation & $\begin{array}{c}\text { Multiple myeloma cells [103] and Burkitt's } \\
\text { lymphoma [104] }\end{array}$ \\
\hline PUMA & DNA hypermethylation & Downregulation & $\begin{array}{c}\text { Multiple myeloma cells [103] and Burkitt's } \\
\text { lymphoma [104] }\end{array}$ \\
\hline$B A D$ & DNA hypermethylation & Downregulation & Multiple myeloma cells [103] \\
\hline$B C L-2 L 10$ & DNA hypermethylation & Downregulation & Gastric cancer [105] and leukemia [106] \\
\hline BIK & DNA hypermethylation & Downregulation & $\begin{array}{l}\text { Glioma [107], RCC [108], prostate cancer } \\
\text { [109], and myeloma [110] }\end{array}$ \\
\hline BNIP3 & DNA hypermethylation & Downregulation & $\begin{array}{c}\text { Gastric cancer [111], colorectal cancer [112], } \\
\text { leukemia [113], and HCC [114] }\end{array}$ \\
\hline$H R K$ & DNA hypermethylation & Downregulation & $\begin{array}{l}\text { Colorectal, gastric [115], GBM [116], } \\
\text { PCNSL [117], and prostate cancer [118] }\end{array}$ \\
\hline
\end{tabular}

Table 2. Epigenetic modification of core apoptotic machinery by miRNAs.

\begin{tabular}{|c|c|c|c|}
\hline miRNA & miRNA Status in Cancer & Target Gene \& Outcome & Cancer Type \\
\hline $\operatorname{miR}-29 b$ & Downregulated & HRK upregulation & $\begin{array}{l}\text { Lung [187], prostate [188], bladder [189], } \\
\text { and ovarian cancers [190] and GBM [191] }\end{array}$ \\
\hline $\begin{array}{c}\text { miR-193a-3p } \\
\text { miR-512-5p, } \\
\text { miR-153, } \\
\text { miR-133B }\end{array}$ & Hypermethylated & MLC1 upregulation & $\begin{array}{c}\text { AML [192], gastric tumors [193], GBM } \\
\text { [194], and lung cancer [195] }\end{array}$ \\
\hline miR-127 & Hypermethylated & BCL-6 upregulation & $\begin{array}{c}\text { Bladder, prostate, breast, and lung cancer } \\
\text { and lymphoma [197] }\end{array}$ \\
\hline $\begin{array}{l}\text { miR-221, } \\
\text { miR-222 }\end{array}$ & Upregulated & $\begin{array}{l}\text { PUMA and CASPASE-3 } \\
\text { downregulation }\end{array}$ & Bladder [203] and glioma [204] \\
\hline $\begin{array}{l}\text { miR-17-92, } \\
\text { miR-106b-93-25 }\end{array}$ & Overexpressed & BIM downregulation & $\begin{array}{l}\text { Lung, colon, lymphoma, medulloblastoma, } \\
\text { and multiple myeloma }[206,207]\end{array}$ \\
\hline miR-135a & Downregulated & BCL-xL upregulation & $\begin{array}{c}\text { Hodgkin lymphoma, AML [210], and } \\
\text { ovarian cancer [211] }\end{array}$ \\
\hline $\operatorname{miR}-451$ & Downregulated & BCL-2 upregulation & Gastric cancer [216] \\
\hline
\end{tabular}


Table 3. Epigenetic modification of apoptosis regulatory pathways and genes.

\begin{tabular}{|c|c|c|}
\hline Other Apoptosis Related Genes & Epigenetic Modification & Outcome \\
\hline$D A P K$ & DNA hypermethylation [121-123] & Downregulation \\
\hline HIC1 & DNA hypermethylation $[124,125]$ & Downregulation \\
\hline$p 16^{I N K 4 a}$ & DNA hypermethylation [119] & Downregulation \\
\hline$A P C$ & DNA hypermethylation [119] & Downregulation \\
\hline TP53 & DNA hypermethylation [126] & Downregulation \\
\hline RASSF1 & DNA hypermethylation [127-130] & Downregulation \\
\hline \multirow{2}{*}{ MGMT } & DNA hypermethylation $[119,120]$ & Downregulation \\
\hline & Increasing H3K4me3 [35] & Downregulation \\
\hline \multirow{2}{*}{$B R C A 1$} & DNA Hypermethylation [119] & Downregulation \\
\hline & Increased H3K4me3 [35] & Downregulation \\
\hline MLH1 & $\begin{array}{c}\text { DNA hypermethylation [119] } \\
\text { Decreased H3K4 methylation [158] }\end{array}$ & Downregulation \\
\hline$p S 2$ & DNA hypomethylation [147] & Upregulation \\
\hline HOX11 & DNA hypomethylation [148] & Upregulation \\
\hline$c-M Y C$ & DNA hypomethylation $[149,150]$ & Upregulation \\
\hline$c-N-R A S$ & DNA hypomethylation $[149,150]$ & Upregulation \\
\hline \multicolumn{3}{|l|}{ MRE11 } \\
\hline \multicolumn{3}{|l|}{$R A D 50$} \\
\hline NBS1 & H2A.X-Y142 phosphorylation $[162,163]$ & Binding to $\gamma-\mathrm{H} 2 \mathrm{~A} . \mathrm{X}$ sites is blocked \\
\hline \multicolumn{3}{|c|}{ 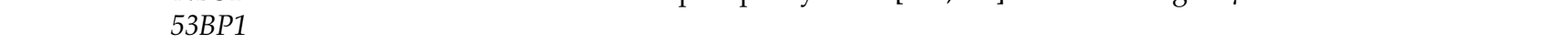 } \\
\hline \multicolumn{3}{|l|}{$B R C A 1$} \\
\hline$N F-\kappa B$ & H2B-S14ph [166] & \multirow{2}{*}{$\begin{array}{c}\text { Inhibited by reduced nuclear trafficking } \\
\text { Half-life and DNA binding affinity is } \\
\text { increased }\end{array}$} \\
\hline E2F1 & Protein acetylation [174] & \\
\hline KU70 & Protein acetylation [175] & Interaction with $B A X$ is disrupted \\
\hline
\end{tabular}

\section{Reprogramming the Cancer Epigenome by Epigenetic Drugs to Trigger Tumor Cell Death}

Given the importance of epigenetic changes in cancer, reversion of DNA and histone modifications by epigenetic drug (Epi-drug) interventions can provide a therapeutic advantage for various type of cancers. To this end, several drugs that target the epigenetic landscape of tumor cells have been developed and received clinical attention. Some of these "Epi-drugs" and their implications are summarized below.

DNMT1 inhibitors result in gradual hypomethylation across cell divisions and lead to elevated expression of tumor suppressor genes. Azacitidine, decitabine, guadecitabine, and 4-thio-2-deoxycytidine are DNMT1 inhibitors designed for clinical use [224,225]. Azacitidine and its deoxy derivative decitabine are approved by the US Food and Drug Administration (FDA) for treatment of myelodysplastic syndromes (MDS) and AML since they decrease malignant cell burden and improve blood cell count and patient survival $[226,227]$. Guadecitabine has a longer effective half-life due to its improved pharmacology and pharmacodynamics, and it has shown promise in early clinical trials [228]. 4-Thio-2deoxycytidine is orally bioavailable and is currently in a Phase I trial in patients with advanced solid tumors [224]. Separately, mutated forms of isocitrate dehydrogenase (IDH1 and $I D H 2$ ) genes are known to be associated with aberrant DNA methylation in cancer. To this end, IDH1 and IDH2 inhibitors, AG-120, AG-221, AG-881, and IDH305, are currently in clinical trials for low-grade glioma and AML patients.

HDAC inhibitors constitute the largest group of epigenetic drugs and are known to exert their activity through maintaining the expression of tumor suppressor genes. Vorinostat (SAHA) [229,230], belinostat [231], and romidepsin [232,233] are FDA-approved for treatment of cutaneous or peripheral T-cell lymphoma. Panobinostat is approved for treatment of drug-resistant multiple myeloma in combination with the proteasome inhibitor bortezomib [234].

Histone acetylation readers, i.e., the bromodomain and extra-terminal (BET) proteins, are also pharmacological targets for cancer therapy. Of these, BRD4 inhibitor OTX015 
mediates a rapid tumor regression with low toxicity [235]. Other BET inhibitors, such as ABBV-075, BMS-986158, and GSK2820151, are also in clinical trials for several malignancies.

The histone methyltransferase EZH2 generates the H3K27me3 mark, which leads to transcriptional repression [236]. EZH2 inhibitors, such as tazemetostat, CPI-1205, DS3201, and GSK2816126, are in clinical trials. Inhibition of EZH2 blocks proliferation of the drug-resistant stem-cell population, thereby preventing tumor growth [237]. Pinometostat, an inhibitor of H3K79 methyltransferase DOT1L, recently completed a Phase I clinical trial in AML patients. The demethylase LSD1 gene has been shown to play an important role in cancer and is very highly expressed in several cancer cell lines $[63,238,239]$. LSD1 inhibitors GSK2879552 and INCB059872 are in clinical trials for patients with AML, MDS, and small-cell lung cancer.

As another approach, miRNAs have high potential as therapeutic tools against cancer due to their ability to regulate multiple targets. Therapeutic strategies focus mainly on either reactivation of tumor suppressor genes through inhibition of oncogenic miRNAs or inhibition of oncogenic gene activity by supplementing cells with miRNA mimics. miRNA inhibitors includes antisense anti-miR oligonucleotides (AMOs, antagomirs) [240], locked nucleic acid (LNA) [241], miRNA sponges [242], and small-molecule inhibitors of miRNAs (SMIR) [243]. To exemplify, LNA silencing of miR-21 reduced cell viability through increasing intracellular caspases activity in glioblastomas [244]. An miR-15a mimic triggered apoptosis and prevented proliferation of prostate cancer cell lines [179]. The Let-7 miRNA precursor blocked proliferation of tumors in K-ras mutant mouse [245,246]. The miR-34 mimic MRX34 resulted in tumor regression in liver cancer orthotopic mouse models [247]. In a Phase I clinical trial (NCT01829971), MRX34 showed strong activity in hepatocellular carcinoma, renal cell carcinoma, and melanoma through repression of target oncogenes namely FOXP1, BCL2, HDAC1, and CTNNB1 [248]. However, the trial was halted due to immunological adverse effects. Intravenous administration of tumor suppressive miR-16 mimic was under a Phase I clinical (NCT02369198) for advanced nonsmall-cell lung cancer (NSCLC) and malignant mesothelioma (MPM), whereby efficacy and good tolerability were reported. MRG-106, a synthetic microRNA antagonist of miR-155, is currently under a Phase II trial for patients with cutaneous T-cell lymphoma (NCT03713320). In addition, DNMT inhibitor 5-aza-2'-deoxycytidine and HDAC inhibitor 4-phenylbutyric acid were shown to induce miR512-5p expression in human gastric cancer to trigger apoptosis by suppressing the Mcl-1 [193]. HDAC inhibitors vorinostat and trichostatin A (TSA) decrease proliferation and increase apoptosis in colorectal cancer by downregulating miR-17-92 cluster expression, consequently elevating PTEN, BCL-2L11, and CDKN1A expression [249].

Epigenetic modulations can also be utilized to overcome drug resistance in several cancer types through a combinatorial treatment approach. Several cell culture $[250,251]$ and in vivo models [252-254] evidenced the efficacy of combinatorial treatment of DNMT and HDAC inhibitors for various cancer cells. Combinatorial treatment of HDAC inhibitor TSA with the DNMT inhibitor decitabine results in reactivation of densely methylated tumor suppressor genes [250]. TSA, belinostat, and vorinostat show synergistic activity with conventional chemotherapeutic agents such as paclitaxel [255], gemcitabine [256], cisplatin [257], etoposide, and doxorubicin [258]. Decitabine acts synergistically with paclitaxel $[259,260]$ and cisplatin [254]. Non-small-cell lung cancer cells are sensitized to EGF tyrosine kinase inhibitors (TKIs) by a HDAC inhibitor [261]. Bromodomain inhibitor JQ1 similarly sensitizes T-cell acute lymphoblastic leukemia to $\gamma$-secretase inhibitor-mediated apoptosis [262]. HDAC inhibitors can also sensitize cancer cells to ionizing radiationmediated apoptosis by modulating cell cycle and growth-related gene expression. HDAC inhibitor sodium butyrate elevates the radiosensitivity of human colon carcinoma cell lines [263]. TSA, entinostat, valproic acid, tributyrin, vorinostat, bicyclic depsipeptide, and hydroxamic acid analogues were shown to sensitize various cancer cell lines toward ionizing radiation $[264,265]$. 
Epi-dugs currently under investigation for various malignancies are summarized in Table 4.

Table 4. Epi-drugs under investigation.

\begin{tabular}{|c|c|c|c|c|}
\hline $\begin{array}{c}\text { Targeted } \\
\text { Epigenetic } \\
\text { Modification }\end{array}$ & Class & Agent & $\begin{array}{l}\text { FDA Approval } \\
\text { Status }\end{array}$ & Targeted Disease \\
\hline \multirow{8}{*}{$\begin{array}{c}\text { DNA } \\
\text { Methylation }\end{array}$} & \multirow{4}{*}{$\begin{array}{l}\text { DNMT1 } \\
\text { inhibitors }\end{array}$} & Azacitidine & Approved (2004) & MDS and AML \\
\hline & & Decitabine & Approved (2006) & MDS and AML \\
\hline & & Guadecitabine & Clinical trial & $\begin{array}{c}\text { Liver, pancreatic, bile duct, or gallbladder cancer } \\
(\text { NCT03257761), non-small-cell lung cancer } \\
\text { (NCT03220477), kidney cancer (NCT03220477), } \\
\text { AML (NCT02878785), and urothelial cancer } \\
\text { (NCT03179943) }\end{array}$ \\
\hline & & $\begin{array}{l}\text { 4-Thio-2- } \\
\text { deoxycytidine } \\
\text { (TdCyd) }\end{array}$ & Clinical trial & Solid tumors (NCT02423057) \\
\hline & \multirow{4}{*}{$\begin{array}{l}\text { IDH1 and IDH2 } \\
\text { inhibitors }\end{array}$} & $\begin{array}{c}\text { AG-120 } \\
\text { (Ivosidenib) }\end{array}$ & Clinical trial & $\begin{array}{c}\text { AML (NCT03173248), myelodysplastic syndrome, } \\
\text { chronic myelomonocytic leukemia } \\
\text { (NCT03564821), and hematologic malignancies } \\
\text { (NCT03471260) }\end{array}$ \\
\hline & & $\begin{array}{c}\text { AG-221 } \\
\text { (Enasidenib) }\end{array}$ & Clinical trial & $\begin{array}{c}\text { AML (NCT03013998, NCT02577406, } \\
\text { NCT03825796, NCT03728335, NCT03683433, } \\
\text { NCT03881735) and MDS (NCT03383575) }\end{array}$ \\
\hline & & $\begin{array}{c}\text { AG-881 } \\
\text { (Vorasidenib) }\end{array}$ & Clinical trial & Hematologic malignancies (NCT02492737) \\
\hline & & IDH305 & Clinical trial & Low-grade gliomas (NCT02987010) \\
\hline \multirow{9}{*}{$\begin{array}{l}\text { Histone } \\
\text { Acetylation }\end{array}$} & \multirow{5}{*}{$\begin{array}{l}\text { HDAC } \\
\text { inhibitors }\end{array}$} & $\begin{array}{l}\text { Vorinostat } \\
\text { (SAHA) }\end{array}$ & Approved (2006) & Cutaneous or peripheral T-cell lymphoma \\
\hline & & Belinostat & Approved (2014) & Peripheral T-cell lymphoma \\
\hline & & Romidepsin & Approved (2009) & Cutaneous or peripheral T-cell lymphoma \\
\hline & & Trichostatin A & Clinical trial & Hematologic malignancies (NCT03838926) \\
\hline & & Panobinostat & Approved (2015) & Multiple myeloma \\
\hline & \multirow{4}{*}{$\begin{array}{l}\text { Histone } \\
\text { acetylation } \\
\text { reader } \\
\text { inhibitors }\end{array}$} & OTX015 & Clinical trial & Hematologic malignancies (NCT01713582) \\
\hline & & $\begin{array}{c}\text { ABBV-075 } \\
\text { (Mivebresib) }\end{array}$ & Clinical trial & $\begin{array}{c}\text { Breast cancer, non-small-cell lung cancer, AML, } \\
\text { multiple myeloma, prostate cancer, small-cell } \\
\text { lung cancer, and non-Hodgkin's lymphoma } \\
\text { (NCT02391480) }\end{array}$ \\
\hline & & BMS-986158 & Clinical trial & $\begin{array}{c}\text { Advanced cancers (NCT02419417), refractory } \\
\text { solid tumors, central nervous system tumors, or } \\
\text { lymphoma (NCT03936465) }\end{array}$ \\
\hline & & GSK2820151 & Clinical trial & $\begin{array}{l}\text { Advanced or recurrent solid tumors } \\
\text { (NCT02630251) }\end{array}$ \\
\hline \multirow{5}{*}{$\begin{array}{l}\text { Histone } \\
\text { Methylation }\end{array}$} & \multirow{5}{*}{$\begin{array}{l}\text { HMT } \\
\text { inhibitors }\end{array}$} & Tazemetostat & Clinical trial & $\begin{array}{l}\text { Advanced solid tumors, non-Hodgkin's } \\
\text { lymphoma, histiocytic disorders (NCT03213665), } \\
\text { synovial sarcoma (NCT02601937), urothelial } \\
\text { carcinoma (NCT03854474), and ovarian or } \\
\text { endometrial cancer (NCT03348631) }\end{array}$ \\
\hline & & CPI-1205 & Clinical trial & $\begin{array}{c}\text { Castration-resistant prostate cancer } \\
(\text { NCT03480646) }\end{array}$ \\
\hline & & $\begin{array}{c}\text { DS-3201 } \\
\text { (Valemetostat) }\end{array}$ & Clinical trial & $\begin{array}{c}\text { Lymphomas (NCT02732275), AML, and ALL } \\
\text { (NCT03110354) }\end{array}$ \\
\hline & & GSK2816126 & Clinical trial & $\begin{array}{c}\text { Diffuse large B-cell lymphoma, transformed } \\
\text { follicular lymphoma, other non-Hodgkin's } \\
\text { lymphomas, solid tumors, and multiple myeloma } \\
\text { (NCT02082977) }\end{array}$ \\
\hline & & Pinometostat & Clinical trial & AML (NCT03724084, NCT03701295) \\
\hline
\end{tabular}


Table 4. Cont.

\begin{tabular}{|c|c|c|c|c|}
\hline $\begin{array}{c}\text { Targeted } \\
\text { Epigenetic } \\
\text { Modification }\end{array}$ & Class & Agent & $\begin{array}{l}\text { FDA Approval } \\
\text { Status }\end{array}$ & Targeted Disease \\
\hline & \multirow{2}{*}{$\begin{array}{l}\text { HDM } \\
\text { inhibitors }\end{array}$} & GSK2879552 & Clinical trial & $\begin{array}{l}\text { Small-cell lung carcinoma (NCT02034123) and } \\
\text { AML (NCT02177812) }\end{array}$ \\
\hline & & INCB059872 & Clinical trial & $\begin{array}{l}\text { Ewing sarcoma (NCT03514407), solid tumors, } \\
\text { and hematologic malignancy (NCT02712905) }\end{array}$ \\
\hline \multirow{3}{*}{$\begin{array}{l}\text { miRNA } \\
\text { Regulation }\end{array}$} & \multirow[b]{2}{*}{ miRNA mimics } & MesomiR-1 & Clinical trial & NSCLC and MPM (NCT02369198) \\
\hline & & MRX34 & Clinical trial & $\begin{array}{c}\text { Hepatocellular carcinoma, renal cell carcinoma, } \\
\text { and melanoma (NCT01829971) }\end{array}$ \\
\hline & $\begin{array}{l}\text { miRNA } \\
\text { antagonist }\end{array}$ & MRG-106 & Clinical trial & T-cell lymphoma (NCT03713320) \\
\hline
\end{tabular}

Modulation of death receptor-mediated pathways by Epi-drugs has been one successful approach for better apoptosis response of tumor cells. To this end, HDAC inhibitors MS275 [266], SAHA [267], valproic acid [268], depsipeptide [269], SBHA [270], and LAQ824 [271] have been shown to augment TRAIL responses in various tumor types including prostate cancer, primary myeloid leukemia, melanoma, breast cancer, medulloblastoma, glioblastoma, and CLL. HDAC-mediated sensitization involves upregulating the DR expression and proapoptotic gene activity (BID, BAD, CASPASES, P21, BAK, and $B A X)$ and downregulating antiapoptotic proteins (e.g., Cflar, Bcl-2, Bcl-xL, Xiap, Mcl1, Survivin, and CyclinD1). MS275 elevates acetylation of $\mathrm{H} 3$ and $\mathrm{H} 4$ at the DR4 promoter and causes an increase in TRAIL receptor expression in medulloblastoma cells. Under combinational treatment with MS275, medulloblastoma cells are much more prone to TRAIL-induced cell death [170]. HDAC inhibitors can also induce expression of proapoptotic genes such as $B A X$ and $B A K$ while blocking the expression of antiapoptotic genes such as XIAP and CFLAR, consequently sensitizing tumor cells to extrinsic and intrinsic apoptosis [52].

On the other hand, some epigenetic changes might contribute to apoptosis resistance due to gene silencing. Modulation of DNA methylation with the methyltransferase inhibitor 5-aza-2'-deoxycytidine has been proven to be effective in modulating the TRAIL response via restored caspase-8 expression [272-274]. Combination of the DNMT inhibitor decitabine with valproic acid significantly increases caspase-8 expression in SCLC and sensitizes tumor cells to TRAIL [275]. DNMT1 and DNMT3b silencing was shown to sensitize human hepatoma cells via upregulation of DR5 and caspase-8 [276]. Similarly, in Burkitt's lymphoma, DNMT1 inhibitor Iso-3 synergizes with TRAIL via a reduction in survivin expression and induction of DR5 surface expression [277]. Taken together, epigenetic modulation of apoptosis sensitivity/resistance with Epi-drugs can serve as a promising approach for cancer therapy.

There are various challenges for the implementation of epigenetic drugs in clinical use. First of all, epigenetic factors reside in large chromatin complexes and act in interplay to regulate gene expression. Therefore, targeting a single epigenetic factor might have unwanted effects on other chromatin-related proteins [278]. To exemplify, targeting histone deacetylases (by vorinostat, sodium butyrate, or TSA) can alter the methylation status, as well as chromatin remodeling, of the targeted location as in the case of the effect of HDAC inhibitors on histone methyltransferase JARID1 [279]. Therefore, in vitro genetic studies or assays for compound screening might overlook that crosstalk between epigenetic factors. In vivo screening assays with focused chemical or genetic libraries for the epigenetic enzymes can overcome this obstacle. Secondly, substrates of epigenetic enzymes are not confined to chromatin proteins, but they may include oncogenes as in the cases of p300/CBP-mediated acetylation and SMYD2-mediated methylation of p53 [280,281]. Therefore, off-target effects of the potential epigenetic compounds should be deeply considered. This off-target effect of epigenetic modifier enzymes could be minimized by 
sequence-specific gene modulation through DNA-targeting tools, as well as through temporal control of epigenetic modulation with the help of optogenetics. Transcriptional activator-like effectors (TALEs) and clustered regularly interspaced short palindromic repeat (CRISPR)/Cas approaches are utilized to localize epigenetic modifier enzymes to specific DNA sequences [282]. The catalytic domain of an epigenetic enzyme can be fused to dCas9 and modulate the epigenome at particular locations [283]. On the other hand, optogenetics enable temporally specific modulation of the epigenome with the help of the light-sensitive protein Cryptochrome 2 (Cry 2) [284].

Another challenge for the utilization of epigenetic drugs in clinical use is their low isoform selectivity. To exemplify, DNMT inhibitors simultaneously target DNMT1, 3A, and $3 \mathrm{~B}$; therefore, it is challenging to understand effects of different isoforms in tumorigenesis. Most of the time, inhibition of a single epigenetic enzyme may not possess sustained effects due to compensation of the epigenetic mark by other epigenetic modifiers. Combinational therapeutics targeting multiple epigenetic marks of the target genomic loci is, therefore, expected to result in sustained effects for many cell divisions [285,286].

Arranging the treatment period for epigenetic drugs is also challenging since epigenetic programming takes time to exert its function. On the other hand, low-dose treatments showed a superior effect without causing immediate cytotoxicity [287]. Overall, efficient transport and delivery systems, which can readily and specifically target tumor tissues, and low-dose administration without causing general toxicity will be two key strategies for effective future Epi-drug based cancer treatments.

\section{Conclusions and Future Perspectives}

Evasion of apoptosis plays a major role for the emergence and progression of a wide variety of cancers. Modulation of apoptosis-related genes via epigenetic alterations has gained increasing attention as our comprehension of the cancer epigenome has rapidly grown with the discovery of novel epigenetic modifier enzymes and their target oncogenes/tumor suppressors. Global changes of epigenome via aberrant modifications of DNA and histones, as well as altered miRNA expression, modulate the expression of genes critical to apoptosis and render malignant cells resistant to current therapies. Increased understanding of tumor-specific epigenetic alteration of apoptosis will enable the discovery of novel targeted therapies utilizing Epi-drugs. Despite the complexity and heterogeneous nature of cancer, Epi-drugs hold great promise for improved survival of patients alone or in combinatorial approach with other therapeutic modalities due to their potential of resetting the cancer epigenome. Detection of the clear pattern of epigenetic changes in early versus late stages of tumors via high-throughput, robust, and affordable methodologies will ultimately lead to rapid discovery of novel epigenetic biomarkers and production of effective Epi-drugs. Optimization of dosage and timing of Epi-drugs will enable to revert therapy resistance and to overcome side-effects which are currently main obstacles for cancer therapy. Ultimately, reprogramming the epigenome of cancer cells toward more apoptosis-mediated cell death may become possible with Epi-drugs. However, open questions in field of epigenetics (Is there a histone code copied during DNA replication in cancers? How is gene regulation controlled by noncoding elements like introns in normal versus cancer cells? How do environmental and dietary factors affect the epigenetic phenotype of tumor cells?) remain to be answered for the development of personalized and effective treatment modalities for cancer.

Author Contributions: Conceptualization, E.O.-G. and T.B.-O.; writing and image generation, E.O.G.; critical editing and supervision, T.B.-O.; All authors have read and agreed to the published version of the manuscript.

Funding: Financial support was obtained from The Scientific and Technological Research Council of Turkey (TUBITAK) (1001 \#311S251). The authors gratefully acknowledge the use of the services and facilities of the Koç University Research Center for Translational Medicine (KUTTAM), funded by the Presidency of Turkey, Presidency of Strategy and Budget. 
Institutional Review Board Statement: Not applicable.

Informed Consent Statement: Not applicable.

Data Availability Statement: Not applicable.

Conflicts of Interest: The authors declare no conflict of interest.

\section{References}

1. Green, D.R. Means to an End: Apoptosis and Other Cell Death Mechanisms; Cold Spring Harbor Laboratory Press: Cold Spring Harbor, NY, USA, 2010; ISBN 9780879698874.

2. Wyllie, A.H.; Kerr, J.F.R.; Currie, A.R. Cell Death: The Significance of Apoptosis. Int. Rev. Cytol. 1980, 68, 251-306. [CrossRef]

3. Hanahan, D.; Weinberg, R.A. The Hallmarks of Cancer Review Douglas. Cell 2000, 100, 57-70. [CrossRef]

4. Fernald, K.; Kurokawa, M. Evading apoptosis in cancer. Trends Cell Biol. 2013. [CrossRef]

5. Esteller, M. Epigenetics in cancer. N. Engl. J. Med. 2008, 358, 1148-1159. [CrossRef] [PubMed]

6. Strahl, B.D.; Allis, C.D. The language of covalent histone modifications. Nature 2000, 403, 41-45. [CrossRef]

7. Fesik, S.W. Promoting apoptosis as a strategy for cancer drug discovery. Nat. Rev. Cancer 2005, 5, 876-885. [CrossRef] [PubMed]

8. Shi, Y. Caspase activation, inhibition, and reactivation: A mechanistic view. Protein Sci. 2004, 13, 1979-1987. [CrossRef] [PubMed]

9. Saelens, X.; Festjens, N.; Walle, L.V.; van Gurp, M.; van Loo, G.; Vandenabeele, P. Toxic proteins released from mitochondria in cell death. Oncogene 2004, 23, 2861-2874. [CrossRef]

10. Henry-Mowatt, J.; Dive, C.; Martinou, J.C.; James, D. Role of mitochondrial membrane permeabilization in apoptosis and cancer. Oncogene 2004, 23, 2850-2860. [CrossRef] [PubMed]

11. Zou, H.; Li, Y.; Liu, X.; Wang, X. An APAf-1 - cytochrome C multimeric complex is a functional apoptosome that activates procaspase-9. J. Biol. Chem. 1999, 274, 11549-11556. [CrossRef]

12. Breckenridge, D.G.; Xue, D. Regulation of mitochondrial membrane permeabilization by BCL-2 family proteins and caspases. Curr. Opin. Cell Biol. 2004, 16, 647-652. [CrossRef]

13. Martinou, J.C.; Green, D.R. Breaking the mitochondrial barrier. Nat. Rev. Mol. Cell Biol. 2001, 2, 63-67. [CrossRef] [PubMed]

14. Willis, S.N.; Adams, J.M. Life in the balance: How BH3-only proteins induce apoptosis. Curr. Opin. Cell Biol. 2005, 17, 617-625. [CrossRef] [PubMed]

15. Edlich, F.; Banerjee, S.; Suzuki, M.; Cleland, M.M.; Arnoult, D.; Wang, C.; Neutzner, A.; Tjandra, N.; Youle, R.J. Bcl-xL retrotranslocates Bax from the mitochondria into the cytosol. Cell 2011, 145, 104-116. [CrossRef] [PubMed]

16. Yee, K.S.; Vousden, K.H. Complicating the complexity of p53. Carcinogenesis 2005, 26, 1317-1322. [CrossRef] [PubMed]

17. Wiley, S.R.; Schooley, K.; Smolak, P.J.; Din, W.S.; Huang, C.P.; Nicholl, J.K.; Sutherland, G.R.; Smith, T.D.; Rauch, C.; Smith, C.A.; et al. Identification and characterization of a new member of the TNF family that induces apoptosis. Immunity 1995, 3, 673-682. [CrossRef]

18. Johnstone, R.W.; Frew, A.J.; Smyth, M.J. The TRAIL apoptotic pathway in cancer onset, progression and therapy. Nat. Rev. Cancer 2008, 8, 782-798. [CrossRef]

19. Debatin, K.M.; Krammer, P.H. Death receptors in chemotherapy and cancer. Oncogene 2004, 23, 2950-2966. [CrossRef]

20. Falschlehner, C.; Emmerich, C.H.; Gerlach, B.; Walczak, H. TRAIL signalling: Decisions between life and death. Int. J. Biochem. Cell Biol. 2007, 39, 1462-1475. [CrossRef]

21. Mérino, D.; Lalaoui, N.; Morizot, A.; Schneider, P.; Solary, E.; Micheau, O. Differential inhibition of TRAIL-mediated DR5-DISC formation by decoy receptors 1 and 2. Mol. Cell. Biol. 2006, 26, 7046-7055. [CrossRef]

22. Ashkenazi, A. Directing cancer cells to self-destruct with pro-apoptotic receptor agonists. Nat. Rev. Drug Discov. 2008, 7, 1001-1012. [CrossRef]

23. Wang, X.; Chen, W.; Zeng, W.; Bai, L.; Tesfaigzi, Y.; Belinsky, S.A.; Lin, Y. Akt-mediated eminent expression of c-FLIP and Mcl-1 confers acquired resistance to TRAIL-induced cytotoxicity to lung cancer cells. Mol. Cancer Ther. 2008, 7, 1156-1163. [CrossRef]

24. Li, H.; Zhu, H.; Xu, C.; Yuan, J. Cleavage of BID by Caspase 8 Mediates the Mitochondrial Damage in the Fas Pathway of Apoptosis. Cell 1998, 94, 491-501. [CrossRef]

25. Luo, X.; Budihardjo, I.; Zou, H.; Slaughter, C.; Wang, X. Bid, a Bcl2 interacting protein, mediates cytochrome c release from mitochondria in response to activation of cell surface death receptors. Cell 1998, 94, 481-490. [CrossRef]

26. Du, C.; Fang, M.; Li, Y.; Li, L.; Wang, X. Smac, a Mitochondrial Protein that Promotes Cytochrome c-Dependent Caspase Activation by Eliminating IAP Inhibition. Cell 2000, 102, 33-42. [CrossRef]

27. Barnhart, B.C.; Alappat, E.C.; Peter, M.E. The CD95 Type I/Type II model. Semin. Immunol. 2003, 15, 185-193. [CrossRef]

28. Ozören, N.; El-Deiry, W.S. Defining characteristics of Types I and II apoptotic cells in response to TRAIL. Neoplasia 2002, 4, 551-557. [CrossRef]

29. Tang, D.; Kang, R.; Berghe, T.V.; Vandenabeele, P.; Kroemer, G. The molecular machinery of regulated cell death. Cell Res. 2019, 29, 347-364. [CrossRef]

30. De Almagro, M.C.; Vucic, D. Necroptosis: Pathway diversity and characteristics. Semin. Cell Dev. Biol. 2015, 39, 56-62. [CrossRef]

31. Green, D.R.; Ferguson, T.; Zitvogel, L.; Kroemer, G. Immunogenic and tolerogenic cell death. Nat. Rev. Immunol. 2009, 9, 353-363. [CrossRef]

32. Pasparakis, M.; Vandenabeele, P. Necroptosis and its role in inflammation. Nature 2015, 517, 311-320. [CrossRef] 
33. Chang, W.; Lin, J.; Dong, J.; Li, D. Pyroptosis: An inflammatory cell death implicates in atherosclerosis. Med. Hypotheses 2013, 81, 484-486. [CrossRef]

34. Fritsch, M.; Günther, S.D.; Schwarzer, R.; Albert, M.C.; Schorn, F.; Werthenbach, J.P.; Schiffmann, L.M.; Stair, N.; Stocks, H.; Seeger, J.M.; et al. Caspase-8 is the molecular switch for apoptosis, necroptosis and pyroptosis. Nature 2019. [CrossRef] [PubMed]

35. Trivedi, R.; Mishra, D.P. Trailing TRAIL Resistance: Novel Targets for TRAIL Sensitization in Cancer Cells. Front. Oncol. 2015, 5. [CrossRef] [PubMed]

36. Braeuer, S.J.; Büneker, C.; Mohr, A.; Zwacka, R.M. Constitutively activated nuclear factor-kappaB, but not induced NF-kappaB, leads to TRAIL resistance by up-regulation of X-linked inhibitor of apoptosis protein in human cancer cells. Mol. Cancer Res. 2006, 4, 715-728. [CrossRef]

37. Roué, G.; Pérez-Galán, P.; López-Guerra, M.; Villamor, N.; Campo, E.; Colomer, D. Selective inhibition of IkappaB kinase sensitizes mantle cell lymphoma B cells to TRAIL by decreasing cellular FLIP level. J. Immunol. 2007, 178, 1923-1930. [CrossRef] [PubMed]

38. Lim, B.; Allen, J.E.; Prabhu, V.V.; Talekar, M.K.; Finnberg, N.K.; El-Deiry, W.S. Targeting TRAIL in the treatment of cancer: New developments. Expert Opin. Ther. Targets 2015, 19, 1171-1185. [CrossRef] [PubMed]

39. Holliday, R. The inheritance of epigenetic defects. Science 1987, 238, 163-170. [CrossRef] [PubMed]

40. Tang, W.W.C.; Dietmann, S.; Irie, N.; Leitch, H.G.; Floros, V.I.; Bradshaw, C.R.; Hackett, J.A.; Chinnery, P.F.; Surani, M.A. A unique gene regulatory network resets the human germline epigenome for development. Cell 2015, 161, 1453-1467. [CrossRef]

41. Chen, Q.; Yan, W.; Duan, E. Epigenetic inheritance of acquired traits through sperm RNAs and sperm RNA modifications. Nat. Rev. Genet. 2016, 17, 733-743. [CrossRef]

42. Saha, A.; Wittmeyer, J.; Cairns, B.R. Chromatin remodelling: The industrial revolution of DNA around histones. Nat. Rev. Mol. Cell Biol. 2006, 7, 437-447. [CrossRef] [PubMed]

43. Cosgrove, M.S.; Boeke, J.D.; Wolberger, C. Regulated nucleosome mobility and the histone code. Nat. Struct. Mol. Biol. 2004. [CrossRef] [PubMed]

44. Khorasanizadeh, S. The Nucleosome: From Genomic Organization to Genomic Regulation. Cell 2004, 116, 259-272. [CrossRef]

45. Yun, M.; Wu, J.; Workman, J.L.; Li, B. Readers of histone modifications. Cell Res. 2011, 21, 564-578. [CrossRef]

46. Fan, H.Y.; He, X.; Kingston, R.E.; Narlikar, G.J. Distinct strategies to make nucleosomal DNA accessible. Mol. Cell 2003, 11, 1311-1322. [CrossRef]

47. Fazzio, T.G.; Tsukiyama, T. Chromatin remodeling in vivo: Evidence for a nucleosome sliding mechanism. Mol. Cell 2003, 12, 1333-1340. [CrossRef]

48. Kassabov, S.R.; Zhang, B.; Persinger, J.; Bartholomew, B. SWI/SNF unwraps, slides, and rewraps the nucleosome. Mol. Cell 2003, 11, 391-403. [CrossRef]

49. Mizuguchi, G.; Shen, X.; Landry, J.; Wu, W.H.; Sen, S.; Wu, C. ATP-Driven Exchange of Histone H2AZ Variant Catalyzed by SWR1 Chromatin Remodeling Complex. Science 2004, 303, 343-348. [CrossRef]

50. Ahmad, K.; Henikoff, S. The histone variant H3.3 marks active chromatin by replication-independent nucleosome assembly. Mol. Cell 2002, 9, 1191-1200. [CrossRef]

51. Suto, R.K.; Clarkson, M.J.; Tremethick, D.J.; Luger, K. Crystal structure of a nucleosome core particle containing the variant histone H2A.Z. Nat. Struct. Biol. 2000, 7, 1121-1124. [CrossRef] [PubMed]

52. Bolden, J.E.; Peart, M.J.; Johnstone, R.W. Anticancer activities of histone deacetylase inhibitors. Nat. Rev. Drug Discov. 2006, 5 , 769-784. [CrossRef]

53. Zhang, W.; Xu, J. DNA methyltransferases and their roles in tumorigenesis. Biomark. Res. 2017, 5, 1-8. [CrossRef]

54. Roberti, A.; Dobay, M.P.; Bisig, B.; Vallois, D.; Boéchat, C.; Lanitis, E.; Bouchindhomme, B.; Parrens, M.C.; Bossard, C.; QuintanillaMartinez, L.; et al. Type II enteropathy-associated T-cell lymphoma features a unique genomic profile with highly recurrent SETD2 alterations. Nat. Commun. 2016, 7, 1-13. [CrossRef]

55. Morin, R.D.; Mendez-Lago, M.; Mungall, A.J.; Goya, R.; Mungall, K.L.; Corbett, R.D.; Johnson, N.A.; Severson, T.M.; Chiu, R.; Field, M.; et al. Frequent mutation of histone-modifying genes in non-Hodgkin lymphoma. Nature 2011, 476, 298-303. [CrossRef]

56. Dalgliesh, G.L.; Furge, K.; Greenman, C.; Chen, L.; Bignell, G.; Butler, A.; Davies, H.; Edkins, S.; Hardy, C.; Latimer, C.; et al. Systematic sequencing of renal carcinoma reveals inactivation of histone modifying genes. Nature 2010, 463, 360-363. [CrossRef]

57. Mar, B.G.; Bullinger, L.B.; McLean, K.M.; Grauman, P.V.; Harris, M.H.; Stevenson, K.; Neuberg, D.S.; Sinha, A.U.; Sallan, S.E.; Silverman, L.B.; et al. Mutations in epigenetic regulators including SETD2 are gained during relapse in paediatric acute lymphoblastic leukaemia. Nat. Commun. 2014, 5, 3469. [CrossRef] [PubMed]

58. Kim, K.H.; Roberts, C.W.M. Targeting EZH2 in cancer. Nat. Med. 2016, 22, 128-134. [CrossRef] [PubMed]

59. You, J.S.; Jones, P.A. Cancer Genetics and Epigenetics: Two Sides of the Same Coin? Cancer Cell 2012, 22, 9-20. [CrossRef]

60. Huang, J.; Sengupta, R.; Espejo, A.B.; Lee, M.G.; Dorsey, J.A.; Richter, M.; Opravil, S.; Shiekhattar, R.; Bedford, M.T.; Jenuwein, T.; et al. p53 is regulated by the lysine demethylase LSD1. Nature 2007. [CrossRef] [PubMed]

61. Theisen, E.R.; Pishas, K.I.; Saund, R.S.; Lessnick, S.L. Therapeutic opportunities in Ewing sarcoma: EWS-FLI inhibition via LSD1 targeting. Oncotarget 2016, 7, 17616-17630. [CrossRef]

62. Fiskus, W.; Sharma, S.; Shah, B.; Portier, B.P.; Devaraj, S.G.T.; Liu, K.; Iyer, S.P.; Bearss, D.; Bhalla, K.N. Highly effective combination of LSD1 (KDM1A) antagonist and pan-histone deacetylase inhibitor against human AML cells. Leukemia 2014, 28, 2155-2164. [CrossRef] 
63. Theisen, E.R.; Gajiwala, S.; Bearss, J.; Sorna, V.; Sharma, S.; Janat-Amsbury, M. Reversible inhibition of lysine specific demethylase 1 is a novel anti-tumor strategy for poorly differentiated endometrial carcinoma. BMC Cancer 2014, 14, 752. [CrossRef]

64. Krieg, A.J.; Rankin, E.B.; Chan, D.; Razorenova, O.; Fernandez, S.; Giaccia, A.J. Regulation of the Histone Demethylase JMJD1A by Hypoxia-Inducible Factor $1 \alpha$ Enhances Hypoxic Gene Expression and Tumor Growth. Mol. Cell. Biol. 2010, 30, 344-353. [CrossRef] [PubMed]

65. Ramadoss, S.; Guo, G.; Wang, C.Y. Lysine demethylase KDM3A regulates breast cancer cell invasion and apoptosis by targeting histone and the non-histone protein p53. Oncogene 2017, 36, 47-59. [CrossRef]

66. Ohguchi, H.; Hideshima, T.; Bhasin, M.K.; Gorgun, G.T.; Santo, L.; Cea, M.; Samur, M.K.; Mimura, N.; Suzuki, R.; Tai, Y.T.; et al. The KDM3A-KLF2-IRF4 axis maintains myeloma cell survival. Nat. Commun. 2016, 7, 10258. [CrossRef]

67. Svotelis, A.; Bianco, S.; Madore, J.; Huppé, G.; Nordell-Markovits, A.; Mes-Masson, A.M.; Gévry, N. H3K27 demethylation by JMJD3 at a poised enhancer of anti-apoptotic gene BCL2 determines ER $\alpha$ ligand dependency. EMBO J. 2011, 30, $3947-3961$. [CrossRef]

68. Ene, C.I.; Edwards, L.; Riddick, G.; Baysan, M.; Woolard, K.; Kotliarova, S.; Lai, C.; Belova, G.; Cam, M.; Walling, J.; et al. Histone Demethylase Jumonji D3 (JMJD3) as a Tumor Suppressor by Regulating p53 Protein Nuclear Stabilization. PLoS ONE 2012, 7, e51407. [CrossRef] [PubMed]

69. Yamazaki, J.; Jelinek, J.; Lu, Y.; Cesaroni, M.; Madzo, J.; Neumann, F.; He, R.; Taby, R.; Vasanthakumar, A.; Macrae, T.; et al. TET2 mutations affect Non-CpG island DNA methylation at enhancers and transcription factor-binding sites in chronic myelomonocytic Leukemia. Cancer Res. 2015, 75, 2833-2843. [CrossRef]

70. Teng, S.; Ma, C.; Yu, Y.; Yi, C. Hydroxyurea promotes TET1 expression and induces apoptosis in osteosarcoma cells. Biosci. Rep. 2019. [CrossRef]

71. Sant, D.W.; Mustafi, S.; Gustafson, C.B.; Chen, J.; Slingerland, J.M.; Wang, G. Vitamin C promotes apoptosis in breast cancer cells by increasing TRAIL expression. Sci. Rep. 2018, 8, 1-11. [CrossRef]

72. Lujambio, A.; Calin, G.A.; Villanueva, A.; Ropero, S.; Sánchez-Céspedes, M.; Blanco, D.; Montuenga, L.M.; Rossi, S.; Nicoloso, M.S.; Faller, W.J.; et al. A microRNA DNA methylation signature for human cancer metastasis. Proc. Natl. Acad. Sci. USA 2008, 105, 13556-13561. [CrossRef]

73. Feinberg, A.P.; Koldobskiy, M.A.; Göndör, A. Epigenetic modulators, modifiers and mediators in cancer aetiology and progression. Nat. Rev. Genet. 2016, 17, 284-299. [CrossRef]

74. Figueroa, M.E.; Abdel-Wahab, O.; Lu, C.; Ward, P.S.; Patel, J.; Shih, A.; Li, Y.; Bhagwat, N.; Vasanthakumar, A.; Fernandez, H.F.; et al. Leukemic IDH1 and IDH2 Mutations Result in a Hypermethylation Phenotype, Disrupt TET2 Function, and Impair Hematopoietic Differentiation. Cancer Cell 2010, 18, 553-567. [CrossRef]

75. Fatemi, M.; Pao, M.M.; Jeong, S.; Gal-Yam, E.N.; Egger, G.; Weisenberger, D.J.; Jones, P.A. Footprinting of mammalian promoters: Use of a CpG DNA methyltransferase revealing nucleosome positions at a single molecule level. Nucleic Acids Res. $2005,33$. [CrossRef]

76. Hermann, A.; Goyal, R.; Jeltsch, A. The Dnmt1 DNA-(cytosine-C5)-methyltransferase methylates DNA processively with high preference for hemimethylated target sites. J. Biol. Chem. 2004, 279, 48350-48359. [CrossRef] [PubMed]

77. Okano, M.; Bell, D.W.; Haber, D.A.; Li, E. DNA methyltransferases Dnmt3a and Dnmt3b are essential for de novo methylation and mammalian development. Cell 1999, 99, 247-257. [CrossRef]

78. Hajji, N.; Joseph, B. Epigenetic regulation of cell life and death decisions and deregulation in cancer. Essays Biochem. 2010, 48, 121-146. [CrossRef] [PubMed]

79. Roll, J.D.; Rivenbark, A.G.; Jones, W.D.; Coleman, W.B. DNMT3b overexpression contributes to a hypermethylator phenotype in human breast cancer cell lines. Mol. Cancer 2008, 7, 15. [CrossRef] [PubMed]

80. Turcan, S.; Rohle, D.; Goenka, A.; Walsh, L.A.; Fang, F.; Yilmaz, E.; Campos, C.; Fabius, A.W.M.; Lu, C.; Ward, P.S.; et al. IDH1 mutation is sufficient to establish the glioma hypermethylator phenotype. Nature 2012. [CrossRef] [PubMed]

81. Letouzé, E.; Martinelli, C.; Loriot, C.; Burnichon, N.; Abermil, N.; Ottolenghi, C.; Janin, M.; Menara, M.; Nguyen, A.T.; Benit, P.; et al. SDH Mutations Establish a Hypermethylator Phenotype in Paraganglioma. Cancer Cell 2013, 23, 739-752. [CrossRef]

82. Baylin, S.B.; Jones, P.A. A decade of exploring the cancer epigenome-Biological and translational implications. Nat. Rev. Cancer 2011, 11, 726-734. [CrossRef]

83. Elmallah, M.I.Y.; Micheau, O. Epigenetic regulation of TRAIL signaling: Implication for cancer therapy. Cancers 2019, 11, 850. [CrossRef]

84. Wu, J.; Wood, G.S. Reduction of Fas/CD95 promoter methylation, upregulation of fas protein, and enhancement of sensitivity to apoptosis in cutaneous T-Cell lymphoma. Arch. Dermatol. 2011, 147, 443-449. [CrossRef]

85. Petak, I.; Danam, R.P.; Tillman, D.M.; Vernes, R.; Howell, S.R.; Berczi, L.; Kopper, L.; Brent, T.P.; Houghton, J.A. Hypermethylation of the gene promoter and enhancer region can regulate Fas expression and sensitivity in colon carcinoma. Cell Death Differ. 2003, 10, 211-217. [CrossRef]

86. Van Noesel, M.M.; Van Bezouw, S.; Voûte, P.A.; Herman, J.G.; Pieters, R.; Versteeg, R. Clustering of hypermethylated genes in neuroblastoma. Genes Chromosom. Cancer 2003, 38, 226-233. [CrossRef]

87. Bae, S.I.; Cheriyath, V.; Jacobs, B.S.; Reu, F.J.; Borden, E.C. Reversal of methylation silencing of Apo2L/TRAIL receptor 1 (DR4) expression overcomes resistance of SK-MEL-3 and SK-MEL-28 melanoma cells to interferons (IFNs) or Apo2L/TRAIL. Oncogene 2007, 27, 490-498. [CrossRef] [PubMed] 
88. Horak, P. Contribution of Epigenetic Silencing of Tumor Necrosis Factor-Related Apoptosis Inducing Ligand Receptor 1 (DR4) to TRAIL Resistance and Ovarian Cancer. Mol. Cancer Res. 2005, 3, 335-343. [CrossRef]

89. Cho, S.; Lee, J.H.; Cho, S.B.; Yoon, K.W.; Park, S.Y.; Lee, W.S.; Park, C.H.; Joo, Y.E.; Kim, H.S.; Choi, S.K.; et al. Epigenetic methylation and expression of caspase 8 and survivin in hepatocellular carcinoma. Pathol. Int. 2010, 60, 203-211. [CrossRef]

90. Malekzadeh, K.; Sobti, R.C.; Nikbakht, M.; Shekari, M.; Hosseini, S.A.; Tamandani, D.K.; Singh, S.K. Methylation patterns of Rb1 and Casp-8 promoters and their impact on their expression in bladder cancer. Cancer Invest. 2009, 27, 70-80. [CrossRef] [PubMed]

91. Shivapurkar, N.; Toyooka, S.; Eby, M.T.; Huang, C.X.; Sathyanarayana, U.G.; Cunningham, H.T.; Reddy, J.L.; Brambilla, E.; Takahashi, T.; Minna, J.D.; et al. Differential inactivation of caspase-8 in lung cancers. Cancer Biol. Ther. 2002, 1, 65-69. [CrossRef] [PubMed]

92. Hervouet, E.; Vallette, F.M.; Cartron, P.F. Impact of the DNA methyltransferases expression on the methylation status of apoptosis-associated genes in glioblastoma multiforme. Cell Death Dis. 2010, 1, e8. [CrossRef] [PubMed]

93. Harada, K.; Toyooka, S.; Shivapurkar, N.; Maitra, A.; Reddy, J.L.; Matta, H.; Miyajima, K.; Timmons, C.F.; Tomlinson, G.E.; Mastrangelo, D.; et al. Deregulation of caspase 8 and 10 expression in pediatric tumors and cell lines. Cancer Res. 2002, 62, 5897-5901. [PubMed]

94. San José-Eneriz, E.; Agirre, X.; Jiménez-Velasco, A.; Cordeu, L.; Martín, V.; Arqueros, V.; Gárate, L.; Fresquet, V.; Cervantes, F.; Martínez-Climent, J.A.; et al. Epigenetic down-regulation of BIM expression is associated with reduced optimal responses to imatinib treatment in chronic myeloid leukaemia. Eur. J. Cancer 2009, 45, 1877-1889. [CrossRef] [PubMed]

95. Furukawa, Y. Methylation Silencing of the Apaf-1 Gene in Acute Leukemia. Mol. Cancer Res. 2005, 3, 325-334. [CrossRef]

96. Soengas, M.S.; Capodieci, P.; Polsky, D.; Mora, J.; Esteller, M.; Opitz-Araya, X.; McCombie, R.; Herman, J.G.; Gerald, W.L.; Lazebnik, Y.A.; et al. Inactivation of the apoptosis effector Apaf-1 in malignant melanoma. Nature 2001. [CrossRef]

97. Wang, H.L.; Bai, H.; Li, Y.; Sun, J.; Wang, X.Q. Rationales for expression and altered expression of apoptotic protease activating factor-1 gene in gastric cancer. World J. Gastroenterol. 2007, 13, 5060-5064. [CrossRef]

98. Christoph, F.; Kempkensteffen, C.; Weikert, S.; Köllermann, J.; Krause, H.; Miller, K.; Schostak, M.; Schrader, M. Methylation of tumour suppressor genes APAF-1 and DAPK-1 and in vitro effects of demethylating agents in bladder and kidney cancer. Br. J. Cancer 2006, 95, 1701-1707. [CrossRef]

99. Byun, D.S.; Cho, K.; Ryu, B.K.; Lee, M.G.; Kang, M.J.; Kim, H.R.; Chi, S.G. Hypermethylation of XIAP-associated Factor 1, a Putative Tumor Suppressor Gene from the 17p13.2 Locus, in Human Gastric Adenocarcinomas. Cancer Res. 2003, 63, 7068-7075.

100. Shui, P.T.; Liston, P.; Jian, T.C.; Lin, M.C.M.; Xiao, H.J.; Yang, Y.; Gu, Q.; Shi, H.J.; Ching, T.L.; Hsiang, F.K.; et al. Restoration of XAF1 expression induces apoptosis and inhibits tumor growth in gastric cancer. Int. J. Cancer 2009, 125, 688-697. [CrossRef]

101. Kempkensteffen, C.; Hinz, S.; Schrader, M.; Christoph, F.; Magheli, A.; Krause, H.; Schostak, M.; Miller, K.; Weikert, S. Gene expression and promoter methylation of the XIAP-associated Factor 1 in renal cell carcinomas: Correlations with pathology and outcome. Cancer Lett. 2007, 254, 227-235. [CrossRef]

102. Wang, Y.; Yu, Q.; Cho, A.H.; Rondeau, G.; Welsh, J.; Adamson, E.; Mercola, D.; McClelland, M. Survey of Differentially Methylated Promoters in Prostate Cancer Cell Lines. Neoplasia 2005, 7, 748-IN7. [CrossRef] [PubMed]

103. Pompeia, C.; Hodge, D.R.; Plass, C.; Wu, Y.Z.; Marquez, V.E.; Kelley, J.A.; Farrar, W.L. Microarray analysis of epigenetic silencing of gene expression in the KAS-6/1 multiple myeloma cell line. Cancer Res. 2004, 64, 3465-3473. [CrossRef] [PubMed]

104. Garrison, S.P.; Jeffers, J.R.; Yang, C.; Nilsson, J.A.; Hall, M.A.; Rehg, J.E.; Yue, W.; Yu, J.; Zhang, L.; Onciu, M.; et al. Selection against PUMA Gene Expression in Myc-Driven B-Cell Lymphomagenesis. Mol. Cell. Biol. 2008, 28, 5391-5402. [CrossRef] [PubMed]

105. Da Xu, J.; Cao, X.X.; Long, Z.W.; Liu, X.P.; Furuya, T.; Xu, J.W.; Liu, X.L.; De Xu, Z.; Sasaki, K.; Li, Q.Q. BCL2L10 protein regulates apoptosis/proliferation through differential pathways in gastric cancer cells. J. Pathol. 2011, 223, 400-409. [CrossRef]

106. Fabiani, E.; Leone, G.; Giachelia, M.; D’Alo', F.; Greco, M.; Criscuolo, M.; Guidi, F.; Rutella, S.; Hohaus, S.; Voso, M.T. Analysis of genome-wide methylation and gene expression induced by 5-aza-2'-deoxycytidine identifies BCL2L10 as a frequent methylation target in acute myeloid leukemia. Leuk. Lymphoma 2010, 51, 2275-2284. [CrossRef] [PubMed]

107. Kim, T.Y.; Zhong, S.; Fields, C.R.; Kim, J.H.; Robertson, K.D. Epigenomic profiling reveals novel and frequent targets of aberrant DNA methylation-mediated silencing in malignant glioma. Cancer Res. 2006, 66, 7490-7501. [CrossRef] [PubMed]

108. Sturm, I.; Stephan, C.; Gillissen, B.; Siebert, R.; Janz, M.; Radetzki, S.; Jung, K.; Loening, S.; Dörken, B.; Daniel, P.T. Loss of the tissue-specific proapoptotic BH3-only protein Nbk/Bik is a unifying feature of renal cell carcinoma. Cell Death Differ. 2006, 13, 619-627. [CrossRef]

109. Murphy, T.M.; Sullivan, L.; Lane, C.; O'Connor, L.; Barrett, C.; Hollywood, D.; Lynch, T.; Lawler, M.; Perry, A.S. In silico analysis and DHPLC screening strategy identifies novel apoptotic gene targets of aberrant promoter hypermethylation in prostate cancer. Prostate 2011, 71, 1-17. [CrossRef]

110. Hatzimichael, E.; Dasoula, A.; Kounnis, V.; Benetatos, L.; Nigro, C.L.; Lattanzio, L.; Papoudou-Bai, A.; Dranitsaris, G.; Briasoulis, E.; Crook, T. Bcl2-interacting killer CpG methylation in multiple myeloma: A potential predictor of relapsed/refractory disease with therapeutic implications. Leuk. Lymphoma 2012, 53, 1709-1713. [CrossRef]

111. Sugita, H.; Iida, S.; Inokuchi, M.; Kato, K.; Ishiguro, M.; Ishikawa, T.; Takagi, Y.; Enjoji, M.; Yamada, H.; Uetake, H.; et al. Methylation of BNIP3 and DAPK indicates lower response to chemotherapy and poor prognosis in gastric cancer. Oncol. Rep. 2011, 25, 513-518. [CrossRef] [PubMed] 
112. Hiraki, M.; Kitajima, Y.; Nakafusa, Y.; Nakamura, J.; Hashiguchi, K.; Sumi, K.; Noshiro, H.; Miyazaki, K. CpG island methylation of BNIP3 predicts resistance against S-1/CPT-11 combined therapy in colorectal cancer patients. Oncol. Rep. 2010, $23,191-197$. [CrossRef] [PubMed]

113. Pike, B.L.; Greiner, T.C.; Wang, X.; Weisenburger, D.D.; Hsu, Y.H.; Renaud, G.; Wolfsberg, T.G.; Kim, M.; Weisenberger, D.J.; Siegmund, K.D.; et al. DNA methylation profiles in diffuse large B-cell lymphoma and their relationship to gene expression status. Leukemia 2008, 22, 1035-1043. [CrossRef]

114. Calvisi, D.F.; Ladu, S.; Gorden, A.; Farina, M.; Lee, J.S.; Conner, E.A.; Schroeder, I.; Factor, V.M.; Thorgeirsson, S.S. Mechanistic and prognostic significance of aberrant methylation in the molecular pathogenesis of human hepatocellular carcinoma. J. Clin. Invest. 2007, 117, 2713-2722. [CrossRef]

115. Obata, T.; Toyota, M.; Satoh, A.; Sasaki, Y.; Ogi, K.; Akino, K.; Suzuki, H.; Murai, M.; Kikuchi, T.; Mita, H.; et al. Identification of HRK as a Target of Epigenetic Inactivation in Colorectal and Gastric Cancer. Clin. Cancer Res. 2003, 9, 6410-6418. [PubMed]

116. Nakamura, M.; Ishida, E.; Shimada, K.; Nakase, H.; Sakaki, T.; Konishi, N. Frequent HRK inactivation associated with low apoptotic index in secondary glioblastomas. Acta Neuropathol. 2005, 110, 402-410. [CrossRef]

117. Nakamura, M.; Ishida, E.; Shimada, K.; Nakase, H.; Sakaki, T.; Konishi, N. Defective expression of HRK is associated with promoter methylation in primary central nervous system lymphomas. Oncology 2006, 70, 212-221. [CrossRef]

118. Higuchi, T.; Nakamura, M.; Shimada, K.; Ishida, E.; Hirao, K.; Konishi, N. HRK inactivation associated with promoter methylation and LOH in prostate cancer. Prostate 2008, 68, 105-113. [CrossRef]

119. Esteller, M. Cancer epigenomics: DNA methylomes and histone-modification maps. Nat. Rev. Genet. 2007, 8, 286-298. [CrossRef]

120. Esteller, M.; Garcia-Foncillas, J.; Andion, E.; Goodman, S.N.; Hidalgo, O.F.; Vanaclocha, V.; Baylin, S.B.; Herman, J.G. Inactivation of the DNA-Repair Gene MGMT and the Clinical Response of Gliomas to Alkylating Agents. N. Engl. J. Med. 2000, 343, 1350-1354. [CrossRef]

121. Mittag, F.; Kuester, D.; Vieth, M.; Peters, B.; Stolte, B.; Roessner, A.; Schneider-Stock, R. DAPK promotor methylation is an early event in colorectal carcinogenesis. Cancer Lett. 2006, 240, 69-75. [CrossRef] [PubMed]

122. Toyooka, S.; Toyooka, K.O.; Miyajima, K.; Reddy, J.L.; Toyota, M.; Sathyanarayana, U.G.; Padar, A.; Tockman, M.S.; Lam, S.; Shivapurkar, N.; et al. Epigenetic down-regulation of death-associated protein kinase in lung cancers. Clin. Cancer Res. 2003, 9 , 3034-3041. [CrossRef]

123. Kissil, J.L.; Feinstein, E.; Cohen, O.; Jones, P.A.; Tsai, Y.C.; Knowles, M.A.; Eydmann, M.E.; Kimchi, A. DAP-kinase loss of expression in various carcinoma and B-cell lymphoma cell lines: Possible implications for role as tumor suppressor gene. Oncogene 1997, 15, 403-407. [CrossRef]

124. Fujii, H.; Biel, M.A.; Zhou, W.; Weitzman, S.A.; Baylin, S.B.; Gabrielson, E. Methylation of the HIC-1 candidate tumor suppressor gene in human breast cancer. Oncogene 1998, 16, 2159-2164. [CrossRef]

125. Waha, A.; Waha, A.; Koch, A.; Meyer-Puttlitz, B.; Weggen, S.; Sörensen, N.; Tonn, J.C.; Albrecht, S.; Goodyer, C.G.; Berthold, F.; et al. Epigenetic Silencing of the HIC-1 Gene in Human Medulloblastomas. J. Neuropathol. Exp. Neurol. 2003, 62, 1192-1201. [CrossRef] [PubMed]

126. Agirre, X.; Novo, F.J.; Calasanz, M.J.; Larráyoz, M.J.; Lahortiga, I.; Valgañón, M.; García-Delgado, M.; Vizmanos, J.L. TP53 Is Frequently Altered by Methylation, Mutation, and/or Deletion in Acute Lymphoblastic Leukaemia. Mol. Carcinog. 2003, 38, 201-208. [CrossRef]

127. Juhlin, C.C.; Kiss, N.B.; Villablanca, A.; Haglund, F.; Nordenström, J.; Höög, A.; Larsson, C. Frequent promoter hypermethylation of the APC and RASSF1A tumour suppressors in parathyroid tumours. PLoS ONE 2010, 5, e9472. [CrossRef] [PubMed]

128. Wang, T.; Liu, H.; Chen, Y.; Liu, W.; Yu, J.; Wu, G. Methylation associated inactivation of RASSF1A and its synergistic effect with activated K-Ras in nasopharyngeal carcinoma. J. Exp. Clin. Cancer Res. 2009, 28, 160. [CrossRef]

129. Niklinska, W.; Naumnik, W.; Sulewska, A.; Kozłowski, M.; Pankiewicz, W.; Milewski, R. Prognostic significance of DAPK and RASSF1A promoter hypermethylation in Non-Small Cell Lung Cancer (NSCLC). Folia Histochem. Cytobiol. 2009, 47, 275-280. [CrossRef] [PubMed]

130. Honda, S.; Haruta, M.; Sugawara, W.; Sasaki, F.; Ohira, M.; Matsunaga, T.; Yamaoka, H.; Horie, H.; Ohnuma, N.; Nakagawara, A.; et al. The methylation status of RASSF1A promoter predicts responsiveness to chemotherapy and eventual cure in hepatoblastoma patients. Int. J. Cancer 2008, 123, 1117-1125. [CrossRef] [PubMed]

131. Cooper, D.N.; Youssoufian, H. The CpG dinucleotide and human genetic disease. Hum. Genet. 1988, 78, 151-155. [CrossRef]

132. Rideout, W.M.; Coetzee, G.A.; Olumi, A.F.; Jones, P.A. 5-Methylcytosine as an endogenous mutagen in the human LDL receptor and p53 genes. Science 1990, 249, 1288-1290. [CrossRef]

133. Denissenko, M.F.; Chen, J.X.; Tang, M.-s.; Pfeifer, G.P. Cytosine methylation determines hot spots of DNA damage in the human P53 gene. Proc. Natl. Acad. Sci. USA 1997, 94, 3893-3898. [CrossRef]

134. Martinez-Fernandez, L.; Banyasz, A.; Esposito, L.; Markovitsi, D.; Improta, R. UV-induced damage to DNA: Effect of cytosine methylation on pyrimidine dimerization. Signal. Transduct. Target. Ther. 2017. [CrossRef]

135. Feinberg, A.P.; Vogelstein, B. Hypomethylation distinguishes genes of some human cancers from their normal counterparts. Nature 1983, 301, 89-92. [CrossRef]

136. Gama-sosa, M.A.; Slagel, V.A.; Trewyn, R.W.; Oxenhandler, R.; Kuo, K.C.; Gehrke, C.W.; Ehrlich, M. The 5-methylcytosine content of DNA from human tumors. Nucleic Acids Res. 1983, 11, 6883-6894. [CrossRef]

137. Bedford, M.T.; van Helden, P.D. Hypomethylation of dna in pathological conditions of the human prostate. Cancer Res. 1987. 
138. Wahlfors, J.; Hiltunen, H.; Heinonen, K.; Hmlinen, E.; Alhonen, L.; Jnne, J. Genomic hypomethylation in human chronic lymphocytic leukemia. Blood 1992, 80, 2074-2080. [CrossRef] [PubMed]

139. Lin, C.H.; Hsieh, S.Y.; Sheen, I.S.; Lee, W.C.; Chen, T.C.; Shyu, W.C.; Liaw, Y.F. Genome-wide hypomethylation in hepatocellular carcinogenesis. Cancer Res. 2001, 61, 4238-4243. [PubMed]

140. Kim, Y.-I.; Giuliano, A.; Hatch, K.D.; Schneider, A.; Nour, M.A.; Dallal, G.E.; Selhub, J.; Mason, J.B. Global DNA hypomethylation increases progressively in cervical dysplasia and carcinoma. Cancer 1994, 74, 893-899. [CrossRef]

141. Gaudet, F. Induction of Tumors in Mice by Genomic Hypomethylation. Science 2003, 300, 489-492. [CrossRef] [PubMed]

142. Dante, R.; Dante-Paire, J.; Rigal, D.; Roizes, G. Methylation patterns of long interspersed repeated DNA and alphoid repetitive DNA from human cell lines and tumors. Anticancer Res. 1992, 12, 559-563. [PubMed]

143. Jürgens, B.; Schmitz-Dräger, B.J.; Schulz, W.A. Hypomethylation of L1 LINE sequences prevailing in human urothelial carcinoma. Cancer Res. 1996, 56, 5698-5703. [PubMed]

144. Takai, D. Hypomethylation of LINE1 Retrotransposon in Human Hepatocellular Carcinomas, but Not in Surrounding Liver Cirrhosis. Jpn. J. Clin. Oncol. 2002, 30, 306-309. [CrossRef]

145. Santourlidis, S.; Florl, A.; Ackermann, R.; Wirtz, H.C.; Schulz, W.A. High frequency of alterations in DNA methylation in adenocarcinoma of the prostate. Prostate 1999. [CrossRef]

146. Ehrlich, M. DNA methylation in cancer: Too much, but also too little. Oncogene 2002, 21, 5400-5413. [CrossRef] [PubMed]

147. Martin, V.; Ribieras, S.; Song-Wang, X.G.; Lasne, Y.; Frappart, L.; Rio, M.C.; Dante, R. Involvement of DNA methylation in the control of the expression of an estrogen-induced breast-cancer-associated protein (pS2) in human breast cancers. J. Cell. Biochem. 1997, 65, 95-106. [CrossRef]

148. Watt, P.M.; Kumar, R.; Kees, U.R. Promoter demethylation accompanies reactivation of the HOX11 proto-oncogene in leukemia. Genes Chromosom. Cancer 2000, 29, 371-377. [CrossRef]

149. Sharrard, R.M.; Royds, J.A.; Rogers, S.; Shorthouse, A.J. Patterns of methylation of the c-myc gene in human colorectal cancer progression. Br. J. Cancer 1992, 65, 667-672. [CrossRef] [PubMed]

150. Shen, L.; Fang, J.; Qiu, D.; Zhang, T.; Yang, J.; Chen, S.; Xiao, S. Correlation between DNA methylation and pathological changes in human hepatocellular carcinoma. Hepatogastroenterology 1998, 45, 1753-1759.

151. Rose, N.R.; Klose, R.J. Understanding the relationship between DNA methylation and histone lysine methylation. Biochim. Biophys. Acta Gene Regul. Mech. 2014, 1839, 1362-1372. [CrossRef] [PubMed]

152. Fuks, F.; Hurd, P.J.; Wolf, D.; Nan, X.; Bird, A.P.; Kouzarides, T. The methyl-CpG-binding protein MeCP2 links DNA methylation to histone methylation. J. Biol. Chem. 2003, 278, 4035-4040. [CrossRef]

153. Okitsu, C.Y.; Hsieh, C.-L. DNA Methylation Dictates Histone H3K4 Methylation. Mol. Cell. Biol. 2007, 27, 2746-2757. [CrossRef] [PubMed]

154. Nan, X.; Ng, H.H.; Johnson, C.A.; Laherty, C.D.; Turner, B.M.; Eisenman, R.N.; Bird, A. Transcriptional repression by the methyl-CpG-binding protein MeCP2 involves a histone deacetylase complex. Nature 1998. [CrossRef] [PubMed]

155. Feldman, N.; Gerson, A.; Fang, J.; Li, E.; Zhang, Y.; Shinkai, Y.; Cedar, H.; Bergman, Y. G9a-mediated irreversible epigenetic inactivation of Oct-3/4 during early embryogenesis. Nat. Cell Biol. 2006, 8, 188-194. [CrossRef]

156. Fraga, M.F.; Ballestar, E.; Villar-Garea, A.; Boix-Chornet, M.; Espada, J.; Schotta, G.; Bonaldi, T.; Haydon, C.; Ropero, S.; Petrie, K.; et al. Loss of acetylation at Lys16 and trimethylation at Lys20 of histone H4 is a common hallmark of human cancer. Nat. Genet. 2005, 37, 391-400. [CrossRef]

157. Th'ng, J.P. Histone modifications and apoptosis: Cause or consequence? Biochem. Cell Biol. 2011, 79, 305-311. [CrossRef]

158. Lu, Y.; Chu, A.; Wajapeyee, N.; Turker, M.S.; Glazer, P.M. Abstract 2887: Epigenetic silencing of the DNA repair genes, BRCA1 and MLH1, induced by hypoxic stress in a pathway dependent on the histone demethylase, LSD1. Cancer Res. 2015, 75, 2887. [CrossRef]

159. Lu, J.; Feng, Y.; Wang, X.; Xu, L.; Pan, H.; Zhu, S.; Liang, Q.; Huang, B. The transcription factor ZBP-89 suppresses p16 expression through a histone modification mechanism to affect cell senescence. FEBS J. 2009, 276, 4197-4206. [CrossRef]

160. Yang, X.; Karuturi, R.K.M.; Sun, F.; Aau, M.; Yu, K.; Shao, R.; Miller, L.D.; Tan, P.B.O.; Yu, Q. CDKN1C (p57KIP2) is a direct target of EZH2 and suppressed by multiple epigenetic mechanisms in breast cancer cells. PLoS ONE 2009, 4, e5011. [CrossRef]

161. Richon, V.M.; Sandhoff, T.W.; Rifkind, R.A.; Marks, P.A. Histone deacetylase inhibitor selectively induces p21WAF1 expression and gene-associated histone acetylation. Proc. Natl. Acad. Sci. USA 2000, 97, 10014-10019. [CrossRef] [PubMed]

162. Stucki, M. Histone H2A.X Tyr142 phosphorylation: A novel sWItCH for apoptosis? DNA Repair 2009, 8, 873-876. [CrossRef] [PubMed]

163. Stucki, M.; Clapperton, J.A.; Mohammad, D.; Yaffe, M.B.; Smerdon, S.J.; Jackson, S.P. MDC1 directly binds phosphorylated histone H2AX to regulate cellular responses to DNA double-strand breaks. Cell 2005, 123, 1213-1226. [CrossRef] [PubMed]

164. Cheung, W.L.; Ajiro, K.; Samejima, K.; Kloc, M.; Cheung, P.; Mizzen, C.A.; Beeser, A.; Etkin, L.D.; Chernoff, J.; Earnshaw, W.C.; et al. Apoptotic phosphorylation of histone H2B is mediated by mammalian sterile twenty kinase. Cell 2003, 113, 507-517. [CrossRef]

165. Ajiro, K.; Scoltock, A.B.; Smith, L.K.; Ashasima, M.; Cidlowski, J.A. Reciprocal epigenetic modification of histone H2B occurs in chromatin during apoptosis in vitro and in vivo. Cell Death Differ. 2010, 17, 984-993. [CrossRef] [PubMed]

166. Wong, C.H.; Chan, H.; Ho, C.Y.; Lai, S.K.; Chan, K.S.; Koh, C.G.; Li, H.Y. Apoptotic histone modification inhibits nuclear transport by regulating RCC1. Nat. Cell Biol. 2009, 11, 36-45. [CrossRef] [PubMed] 
167. Hurd, P.J.; Bannister, A.J.; Halls, K.; Dawson, M.A.; Vermeulen, M.; Olsen, J.V.; Ismail, H.; Somers, J.; Mann, M.; Owen-Hughes, T.; et al. Phosporylation of histone H3 Thr-45 is linked to apoptosis. J. Biol. Chem. 2009, 284, 16575-16583. [CrossRef] [PubMed]

168. Kim, K.; Punj, V.; Choi, J.; Heo, K.; Kim, J.-M.; Laird, P.W.; An, W. Gene dysregulation by histone variant H2A.Z in bladder cancer. Epigenetics Chromatin 2013, 6, 34. [CrossRef] [PubMed]

169. Yang, B.; Tong, R.; Liu, H.; Wu, J.; Chen, D.; Xue, Z.; Ding, C.; Zhou, L.; Xie, H.; Wu, J.; et al. H2A.Z regulates tumorigenesis, metastasis and sensitivity to cisplatin in intrahepatic cholangiocarcinoma. Int. J. Oncol. 2018, 52, 1235-1245. [CrossRef]

170. Aguilera, D.G.; Das, C.M.; Sinnappah-Kang, N.D.; Joyce, C.; Taylor, P.H.; Wen, S.; Hasselblatt, M.; Paulus, W.; Fuller, G.; Wolff, J.E.; et al. Reactivation of death receptor 4 (DR4) expression sensitizes medulloblastoma cell lines to TRAIL. J. Neurooncol. 2009, 93, 303-318. [CrossRef]

171. Myzak, M.C.; Dashwood, W.M.; Orner, G.A.; Ho, E.; Dashwood, R.H. Sulforaphane inhibits histone deacetylase in vivo and suppresses tumorigenesis in Apc min mice. FASEB J. 2006, 20, 506-508. [CrossRef]

172. Paschos, K.; Smith, P.; Anderton, E.; Middeldorp, J.M.; White, R.E.; Allday, M.J. Epstein-Barr virus latency in B cells leads to epigenetic repression and CpG methylation of the tumour suppressor gene Bim. PLoS Pathog. 2009, 5, e1000492. [CrossRef]

173. Glozak, M.A.; Sengupta, N.; Zhang, X.; Seto, E. Acetylation and deacetylation of non-histone proteins. Gene 2005, 363, 15-23. [CrossRef]

174. Ianari, A.; Gallo, R.; Palma, M.; Alesse, E.; Gulino, A. Specific role for p300/CREB-binding protein-associated factor activity in E2F1 stabilization in response to DNA damage. J. Biol. Chem. 2004, 279, 30830-30835. [CrossRef]

175. Cohen, H.Y.; Lavu, S.; Bitterman, K.J.; Hekking, B.; Imahiyerobo, T.A.; Miller, C.; Frye, R.; Ploegh, H.; Kessler, B.M.; Sinclair, D.A. Acetylation of the $\mathrm{C}$ terminus of Ku70 by CBP and PCAF controls Bax-mediated apoptosis. Mol. Cell 2004, 13, 627-638. [CrossRef]

176. Friedman, R.C.; Farh, K.K.H.; Burge, C.B.; Bartel, D.P. Most mammalian mRNAs are conserved targets of microRNAs. Genome Res. 2009, 19, 92-105. [CrossRef] [PubMed]

177. Lin, S.; Gregory, R.I. MicroRNA biogenesis pathways in cancer. Nat. Rev. Cancer 2015, 15, 321-333. [CrossRef]

178. Cimmino, A.; Calin, G.A.; Fabbri, M.; Iorio, M.V.; Ferracin, M.; Shimizu, M.; Wojcik, S.E.; Aqeilan, R.I.; Zupo, S.; Dono, M.; et al. miR-15 and miR-16 induce apoptosis by targeting BCL2. Proc. Natl. Acad. Sci. USA 2005, 102, 13944-13949. [CrossRef] [PubMed]

179. Bonci, D.; Coppola, V.; Musumeci, M.; Addario, A.; Giuffrida, R.; Memeo, L.; D’Urso, L.; Pagliuca, A.; Biffoni, M.; Labbaye, C.; et al. The miR-15a-miR-16-1 cluster controls prostate cancer by targeting multiple oncogenic activities. Nat. Med. 2008, 14, 1271-1277. [CrossRef] [PubMed]

180. Bottoni, A.; Piccin, D.; Tagliati, F.; Luchin, A.; Zatelli, M.C.; Uberti, E.C.D. miR-15a and miR-16-1 down-regulation in pituitary adenomas. J. Cell. Physiol. 2005, 204, 280-285. [CrossRef] [PubMed]

181. Sampath, D.; Liu, C.; Vasan, K.; Sulda, M.; Puduvalli, V.K.; Wierda, W.G.; Keating, M.J. Histone deacetylases mediate the silencing of miR-15a, miR-16, and miR-29b in chronic lymphocytic leukemia. Blood 2012, 119, 1162-1172. [CrossRef]

182. Zhang, X.; Chen, X.; Lin, J.; Lwin, T.; Wright, G.; Moscinski, L.C.; Dalton, W.S.; Seto, E.; Wright, K.; Sotomayor, E.; et al. Myc represses miR-15a/miR-16-1 expression through recruitment of HDAC3 in mantle cell and other non-Hodgkin B-cell lymphomas. Oncogene 2012, 31, 3002-3008. [CrossRef] [PubMed]

183. Ji, Q.; Hao, X.; Meng, Y.; Zhang, M.; DeSano, J.; Fan, D.; Xu, L. Restoration of tumor suppressor miR-34 inhibits human p53-mutant gastric cancer tumorspheres. BMC Cancer 2008, 8, 266. [CrossRef] [PubMed]

184. Malumbres, M. MiRNAs and cancer: An epigenetics view. Mol. Aspects Med. 2013, 34, 863-874. [CrossRef] [PubMed]

185. Lodygin, D.; Tarasov, V.; Epanchintsev, A.; Berking, C.; Knyazeva, T.; Körner, H.; Knyazev, P.; Diebold, J.; Hermeking, H. Inactivation of miR-34a by aberrant CpG methylation in multiple types of cancer. Cell Cycle 2008, 7, 2591-2600. [CrossRef] [PubMed]

186. Garzon, R.; Liu, S.; Fabbri, M.; Liu, Z.; Heaphy, C.E.A.; Callegari, E.; Schwind, S.; Pang, J.; Yu, J.; Muthusamy, N.; et al. MicroRNA$29 \mathrm{~b}$ induces global DNA hypomethylation and tumor suppressor gene reexpression in acute myeloid leukemia by targeting directly DNMT3A and 3B and indirectly DNMT1. Blood 2009, 113, 6411-6418. [CrossRef]

187. Yanaihara, N.; Caplen, N.; Bowman, E.; Seike, M.; Kumamoto, K.; Yi, M.; Stephens, R.M.; Okamoto, A.; Yokota, J.; Tanaka, T.; et al. Unique microRNA molecular profiles in lung cancer diagnosis and prognosis. Cancer Cell 2006, 9, 189-198. [CrossRef] [PubMed]

188. Wang, L.H.; Huang, J.; Wu, C.R.; Huang, L.Y.; Cui, J.; Xing, Z.Z.; Zhao, C.Y. Downregulation of miR-29b targets DNMT3b to suppress cellular apoptosis and enhance proliferation in pancreatic cancer. Mol. Med. Rep. 2017, 17, 2113-2120. [CrossRef]

189. Ratert, N.; Meyer, H.A.; Jung, M.; Mollenkopf, H.J.; Wagner, I.; Miller, K.; Kilic, E.; Erbersdobler, A.; Weikert, S.; Jung, K. Reference miRNAs for miRNAome analysis of urothelial carcinomas. PLoS ONE 2012, 7, e39309. [CrossRef]

190. Flavin, R.; Smyth, P.; Barrett, C.; Russell, S.; Wen, H.; Wei, J.; Laios, A.; O’Toole, S.; Ring, M.; Denning, K.; et al. MiR-29b expression is associated with disease-free survival in patients with ovarian serous carcinoma. Int. J. Gynecol. Cancer 2009, 19, $641-647$. [CrossRef]

191. Cortez, M.A.; Nicoloso, M.S.; Shimizu, M.; Rossi, S.; Gopisetty, G.; Molina, J.R.; Carlotti, C.; Tirapelli, D.; Neder, L.; Brassesco, M.S.; et al. miR-29b and miR-125a regulate podoplanin and suppress invasion in glioblastoma. Genes Chromosom. Cancer 2010, 49, 981-990. [CrossRef]

192. Li, Y.; Gao, L.; Luo, X.; Wang, L.; Gao, X.; Wang, W.; Sun, J.; Dou, L.; Li, J.; Xu, C.; et al. Epigenetic silencing of microRNA-193a contributes to leukemogenesis in $\mathrm{t}(8 ; 21)$ acute myeloid leukemia by activating the PTEN/PI3K signal pathway. Blood 2013, 121, 499-509. [CrossRef] 
193. Saito, Y.; Suzuki, H.; Tsugawa, H.; Nakagawa, I.; Matsuzaki, J.; Kanai, Y.; Hibi, T. Chromatin remodeling at Alu repeats by epigenetic treatment activates silenced microRNA-512-5p with downregulation of Mcl-1 in human gastric cancer cells. Oncogene 2009, 28, 2738-2744. [CrossRef]

194. Ghasemi, A.; Fallah, S.; Ansari, M. MIR-153 as a tumor suppressor in glioblastoma multiforme is downregulated by DNA methylation. Clin. Lab. 2016, 59. [CrossRef] [PubMed]

195. Crawford, M.; Batte, K.; Yu, L.; Wu, X.; Nuovo, G.J.; Marsh, C.B.; Otterson, G.A.; Nana-Sinkam, S.P. MicroRNA 133B targets pro-survival molecules MCL-1 and BCL2L2 in lung cancer. Biochem. Biophys. Res. Commun. 2009, 388, 483-489. [CrossRef] [PubMed]

196. Chen, J.; Wang, M.; Guo, M.; Xie, Y.; Cong, Y.S. miR-127 regulates cell proliferation and senescence by targeting BCL6. PLoS ONE 2013, 8, e80266. [CrossRef]

197. Saito, Y.; Liang, G.; Egger, G.; Friedman, J.M.; Chuang, J.C.; Coetzee, G.A.; Jones, P.A. Specific activation of microRNA-127 with downregulation of the proto-oncogene BCL6 by chromatin-modifying drugs in human cancer cells. Cancer Cell 2006, 9, 435-443. [CrossRef] [PubMed]

198. Petrocca, F.; Visone, R.; Onelli, M.R.; Shah, M.H.; Nicoloso, M.S.; de Martino, I.; Iliopoulos, D.; Pilozzi, E.; Liu, C.G.; Negrini, M.; et al. E2F1-Regulated MicroRNAs Impair TGF $\beta$-Dependent Cell-Cycle Arrest and Apoptosis in Gastric Cancer. Cancer Cell 2008, 13, 272-286. [CrossRef]

199. Yang, H.; Lan, P.; Hou, Z.; Guan, Y.; Zhang, J.; Xu, W.; Tian, Z.; Zhang, C. Histone deacetylase inhibitor SAHA epigenetically regulates miR-17-92 cluster and MCM7 to upregulate MICA expression in hepatoma. Br. J. Cancer 2015, 112, 112-121. [CrossRef]

200. Garofalo, M.; Di Leva, G.; Romano, G.; Nuovo, G.; Suh, S.S.; Ngankeu, A.; Taccioli, C.; Pichiorri, F.; Alder, H.; Secchiero, P.; et al. miR-221\&222 Regulate TRAIL Resistance and Enhance Tumorigenicity through PTEN and TIMP3 Downregulation. Cancer Cell 2009, 16, 498-509. [CrossRef]

201. Zhang, C.Z.; Zhang, J.X.; Zhang, A.L.; Shi, Z.D.; Han, L.; Jia, Z.F.; Yang, W.D.; Wang, G.X.; Jiang, T.; You, Y.P.; et al. MiR-221 and miR-222 target PUMA to induce cell survival in glioblastoma. Mol. Cancer 2010, 9, 229. [CrossRef]

202. Jin, X.; Cai, L.; Wang, C.; Deng, X.; Yi, S.; Lei, Z.; Xiao, Q.; Xu, H.; Luo, H.; Sun, J. CASC2/miR-24/miR-221 modulates the TRAIL resistance of hepatocellular carcinoma cell through caspase-8/caspase-3. Cell Death Dis. 2018, 9, 1-12. [CrossRef] [PubMed]

203. Lu, Q.; Lu, C.; Zhou, G.P.; Zhang, W.; Xiao, H.; Wang, X.R. MicroRNA-221 silencing predisposed human bladder cancer cells to undergo apoptosis induced by TRAIL. Urol. Oncol. Semin. Orig. Investig. 2010, 28, 635-641. [CrossRef] [PubMed]

204. Quintavalle, C.; Garofalo, M.; Zanca, C.; Romano, G.; Iaboni, M.; Del Basso De Caro, M.; Martinez-Montero, J.C.; Incoronato, M.; Nuovo, G.; Croce, C.M.; et al. MiR-221/222 overexpession in human glioblastoma increases invasiveness by targeting the protein phosphate PTP. Oncogene 2012, 31, 858-868. [CrossRef] [PubMed]

205. Zhao, Z.N.; Bai, J.X.; Zhou, Q.; Yan, B.; Qin, W.W.; Jia, L.T.; Meng, Y.L.; Jin, B.Q.; Yao, L.B.; Wang, T.; et al. TSA Suppresses miR-106b-93-25 Cluster Expression through Downregulation of MYC and Inhibits Proliferation and Induces Apoptosis in Human EMC. PLoS ONE 2012, 7, e45133. [CrossRef] [PubMed]

206. Hayashita, Y.; Osada, H.; Tatematsu, Y.; Yamada, H.; Yanagisawa, K.; Tomida, S.; Yatabe, Y.; Kawahara, K.; Sekido, Y.; Takahashi, T. A polycistronic MicroRNA cluster, miR-17-92, is overexpressed in human lung cancers and enhances cell proliferation. Cancer Res. 2005, 65, 9628-9632. [CrossRef] [PubMed]

207. He, L.; Thomson, J.M.; Hemann, M.T.; Hernando-Monge, E.; Mu, D.; Goodson, S.; Powers, S.; Cordon-Cardo, C.; Lowe, S.W.; Hannon, G.J.; et al. A microRNA polycistron as a potential human oncogene. Nature 2005, 435, 828-833. [CrossRef]

208. Navarro, A.; Diaz, T.; Martinez, A.; Gaya, A.; Pons, A.; Gel, B.; Codony, C.; Ferrer, G.; Martinez, C.; Montserrat, E.; et al. Regulation of JAK2 by miR-135a: Prognostic impact in classic Hodgkin lymphoma. Blood 2009, 114, 2945-2951. [CrossRef]

209. Wu, H.; Huang, M.; Cao, P.; Wang, T.; Shu, Y.; Liu, P. MiR-135a targets JAK2 and inhibits gastric cancer cell proliferation. Cancer Biol. Ther. 2012, 13, 281-288. [CrossRef]

210. $\mathrm{Xu}, \mathrm{H}$.; Wen, Q. Downregulation of miR-135a predicts poor prognosis in acute myeloid leukemia and regulates leukemia progression via modulating HOXA10 expression. Mol. Med. Rep. 2018, 18, 1134-1140. [CrossRef]

211. Duan, S.; Dong, X.; Hai, J.; Jiang, J.; Wang, W.; Yang, J.; Zhang, W.; Chen, C. MicroRNA-135a-3p is downregulated and serves as a tumour suppressor in ovarian cancer by targeting CCR2. Biomed. Pharmacother. 2018, 107, 712-720. [CrossRef]

212. Nakano, H.; Miyazawa, T.; Kinoshita, K.; Yamada, Y.; Yoshida, T. Functional screening identifies a microRNA, miR-491 that induces apoptosis by targeting Bcl-XLin colorectal cancer cells. Int. J. Cancer 2010, 127, 1072-1080. [CrossRef] [PubMed]

213. Unoki, M.; Nakamura, Y. EGR2 induces apoptosis in various cancer cell lines by direct transactivation of BNIP3L and BAK. Oncogene 2003, 22, 2172-2185. [CrossRef] [PubMed]

214. Wu, Q.; Jin, H.; Yang, Z.; Luo, G.; Lu, Y.; Li, K.; Ren, G.; Su, T.; Pan, Y.; Feng, B.; et al. MiR-150 promotes gastric cancer proliferation by negatively regulating the pro-apoptotic gene EGR2. Biochem. Biophys. Res. Commun. 2010, 392, 340-345. [CrossRef] [PubMed]

215. Beswick, E.J.; Pinchuk, I.V.; Suarez, G.; Sierra, J.C.; Reyes, V.E. Helicobacter pylori CagA-Dependent Macrophage Migration Inhibitory Factor Produced by Gastric Epithelial Cells Binds to CD74 and Stimulates Procarcinogenic Events. J. Immunol. 2014. [CrossRef]

216. Shen, Y.; Gong, J.-M.; Zhou, L.-L.; Sheng, J.-H. MiR-451 as a new tumor marker for gastric cancer. Oncotarget 2017, 8, 56542-56545. [CrossRef]

217. Pfeffer, S.; Zavolan, M.; Grässer, F.A.; Chien, H.; Russo, J.J.; Ju, J.; John, B.; Enright, A.J.; Marks, D.; Sander, C.; et al. Identification of Virus-Encoded MicroRNAs. Science 2004, 304, 734-736. [CrossRef] 
218. Shah, K.M.; Young, L.S. Epstein-Barr virus and carcinogenesis: Beyond Burkitt's lymphoma. Clin. Microbiol. Infect. 2009, 15, 982-988. [CrossRef]

219. Choy, E.Y.-W.; Siu, K.-L.; Kok, K.-H.; Lung, R.W.-M.; Tsang, C.M.; To, K.-F.; Kwong, D.L.-W.; Tsao, S.W.; Jin, D.-Y. An Epstein-Barr virus-encoded microRNA targets PUMA to promote host cell survival. J. Exp. Med. 2008, 205, 2551-2560. [CrossRef] [PubMed]

220. Diaz-Meco, M.T.; Abu-Baker, S. The Par-4/PTEN connection in tumor suppression. Cell Cycle 2009, 8, 2518-2522. [CrossRef]

221. Meng, F.; Henson, R.; Wehbe-Janek, H.; Ghoshal, K.; Jacob, S.T.; Patel, T. MicroRNA-21 Regulates Expression of the PTEN Tumor Suppressor Gene in Human Hepatocellular Cancer. Gastroenterology 2007, 133, 647-658. [CrossRef] [PubMed]

222. Tsukamoto, Y.; Nakada, C.; Noguchi, T.; Tanigawa, M.; Nguyen, L.T.; Uchida, T.; Hijiya, N.; Matsuura, K.; Fujioka, T.; Seto, M.; et al. MicroRNA-375 is downregulated in gastric carcinomas and regulates cell survival by targeting PDK1 and 14-3-3द. Cancer Res. 2010, 70, 2339-2349. [CrossRef]

223. Shen, H.M.; Tergaonkar, V. NFkB signaling in carcinogenesis and as a potential molecular target for cancer therapy. Apoptosis 2009, 14, 348-363. [CrossRef] [PubMed]

224. Thottassery, J.V.; Sambandam, V.; Allan, P.W.; Maddry, J.A.; Maxuitenko, Y.Y.; Tiwari, K.; Hollingshead, M.; Parker, W.B. Novel DNA methyltransferase-1 (DNMT1) depleting anticancer nucleosides, $4^{\prime}$-thio-2' ${ }^{\prime}$-deoxycytidine and 5-aza-4'-thio-2' deoxycytidine. Cancer Chemother. Pharmacol. 2014, 74, 291-302. [CrossRef] [PubMed]

225. Christman, J.K. 5-Azacytidine and 5-aza-2'-deoxycytidine as inhibitors of DNA methylation: Mechanistic studies and their implications for cancer therapy. Oncogene 2002, 21, 5483-5495. [CrossRef] [PubMed]

226. Fenaux, P.; Mufti, G.J.; Hellstrom-Lindberg, E.; Santini, V.; Finelli, C.; Giagounidis, A.; Schoch, R.; Gattermann, N.; Sanz, G.; List, A.; et al. Efficacy of azacitidine compared with that of conventional care regimens in the treatment of higher-risk myelodysplastic syndromes: A randomised, open-label, phase III study. Lancet Oncol. 2009, 10, 223-232. [CrossRef]

227. Lübbert, M.; Suciu, S.; Hagemeijer, A.; Rüter, B.; Platzbecker, U.; Giagounidis, A.; Selleslag, D.; Labar, B.; Germing, U.; Salih, H.R.; et al. Decitabine improves progression-free survival in older high-risk MDS patients with multiple autosomal monosomies: Results of a subgroup analysis of the randomized phase III study 06011 of the EORTC Leukemia Cooperative Group and German MDS Study Group. Ann. Hematol. 2016, 95, 191-199. [CrossRef]

228. Issa, J.P.J.; Roboz, G.; Rizzieri, D.; Jabbour, E.; Stock, W.; O’Connell, C.; Yee, K.; Tibes, R.; Griffiths, E.A.; Walsh, K.; et al. Safety and tolerability of guadecitabine (SGI-110) in patients with myelodysplastic syndrome and acute myeloid leukaemia: A multicentre, randomised, dose-escalation phase 1 study. Lancet Oncol. 2015, 16, 1099-1110. [CrossRef]

229. Duvic, M.; Talpur, R.; Ni, X.; Zhang, C.; Hazarika, P.; Kelly, C.; Chiao, J.H.; Reilly, J.F.; Ricker, J.L.; Richon, V.M.; et al. Phase 2 trial of oral vorinostat (suberoylanilide hydroxamic acid, SAHA) for refractory cutaneous T-cell lymphoma (CTCL). Blood 2007, 109, 31-39. [CrossRef]

230. Olsen, E.A.; Kim, Y.H.; Kuzel, T.M.; Pacheco, T.R.; Foss, F.M.; Parker, S.; Frankel, S.R.; Chen, C.; Ricker, J.L.; Arduino, J.M.; et al. Phase IIB multicenter trial of vorinostat in patients with persistent, progressive, or treatment refractory cutaneous $\mathrm{t}$-cell lymphoma. J. Clin. Oncol. 2007, 25, 3109-3115. [CrossRef]

231. Lee, H.Z.; Kwitkowski, V.E.; Del Valle, P.L.; Ricci, M.S.; Saber, H.; Habtemariam, B.A.; Bullock, J.; Bloomquist, E.; Shen, Y.L.; Chen, X.H.; et al. FDA approval: Belinostat for the treatment of patients with relapsed or refractory peripheral T-cell lymphoma. Clin. Cancer Res. 2015, 21, 2666-2670. [CrossRef]

232. Whittaker, S.J.; Demierre, M.F.; Kim, E.J.; Rook, A.H.; Lerner, A.; Duvic, M.; Scarisbrick, J.; Reddy, S.; Robak, T.; Becker, J.C.; et al Final results from a multicenter, international, pivotal study of romidepsin in refractory cutaneous T-cell lymphoma. J. Clin. Oncol. 2010, 28, 4485-4491. [CrossRef] [PubMed]

233. Piekarz, R.L.; Frye, R.; Turner, M.; Wright, J.J.; Allen, S.L.; Kirschbaum, M.H.; Zain, J.; Prince, H.M.; Leonard, J.P.; Geskin, L.J.; et al. Phase II multi-institutional trial of the histone deacetylase inhibitor romidepsin as monotherapy for patients with cutaneous T-cell lymphoma. J. Clin. Oncol. 2009, 27, 5410-5417. [CrossRef]

234. San-Miguel, J.F.; Hungria, V.T.M.; Yoon, S.S.; Beksac, M.; Dimopoulos, M.A.; Elghandour, A.; Jedrzejczak, W.W.; Günther, A.; Nakorn, T.N.; Siritanaratkul, N.; et al. Panobinostat plus bortezomib and dexamethasone versus placebo plus bortezomib and dexamethasone in patients with relapsed or relapsed and refractory multiple myeloma: A multicentre, randomised, double-blind phase 3 trial. Lancet Oncol. 2014, 15, 1195-1206. [CrossRef]

235. Stathis, A.; Zucca, E.; Bekradda, M.; Gomez-Roca, C.; Delord, J.P.; Rouge, T.d.L.M.; Uro-Coste, E.; de Braud, F.; Pelosi, G.; French, C.A. Clinical response of carcinomas harboring the BRD4-NUT oncoprotein to the targeted bromodomain inhibitor OTX015/MK-8628. Cancer Discov. 2016, 6, 492-500. [CrossRef]

236. Cao, R.; Wang, L.; Wang, H.; Xia, L.; Erdjument-Bromage, H.; Tempst, P.; Jones, R.S.; Zhang, Y. Role of histone H3 lysine 27 methylation in polycomb-group silencing. Science 2002, 298, 1039-1043. [CrossRef]

237. Li, H.; Cai, Q.; Godwin, A.K.; Zhang, R. Enhancer of zeste homolog 2 promotes the proliferation and invasion of epithelial ovarian cancer cells. Mol. Cancer Res. 2010, 8, 1610-1618. [CrossRef] [PubMed]

238. Shi, Y.; Lan, F.; Matson, C.; Mulligan, P.; Whetstine, J.R.; Cole, P.A.; Casero, R.A.; Shi, Y. Histone demethylation mediated by the nuclear amine oxidase homolog LSD1. Cell 2010, 8, 1610-1618. [CrossRef]

239. Schenk, T.; Chen, W.C.; Göllner, S.; Howell, L.; Jin, L.; Hebestreit, K.; Klein, H.U.; Popescu, A.C.; Burnett, A.; Mills, K.; et al. Inhibition of the LSD1 (KDM1A) demethylase reactivates the all-trans-retinoic acid differentiation pathway in acute myeloid leukemia. Nat. Med. 2012, 18, 605-611. [CrossRef] 
240. Garzon, R.; Marcucci, G.; Croce, C.M. Targeting microRNAs in cancer: Rationale, strategies and challenges. Nat. Rev. Drug Discov. 2010, 9, 775-789. [CrossRef]

241. Vester, B.; Wengel, J. LNA (Locked Nucleic Acid): High-affinity targeting of complementary RNA and DNA. Biochemistry 2004, 43, 13233-13241. [CrossRef]

242. Ebert, M.S.; Neilson, J.R.; Sharp, P.A. MicroRNA sponges: Competitive inhibitors of small RNAs in mammalian cells. Nat. Methods 2007, 4, 721-726. [CrossRef]

243. Monroig, P. del C.; Chen, L.; Zhang, S.; Calin, G.A. Small molecule compounds targeting miRNAs for cancer therapy. Adv. Drug Deliv. Rev. 2015, 81, 104-116. [CrossRef] [PubMed]

244. Griveau, A.; Bejaud, J.; Anthiya, S.; Avril, S.; Autret, D.; Garcion, E. Silencing of miR-21 by locked nucleic acid-lipid nanocapsule complexes sensitize human glioblastoma cells to radiation-induced cell death. Int. J. Pharm. 2013, 454, 765-774. [CrossRef]

245. Esquela-Kerscher, A.; Trang, P.; Wiggins, J.F.; Patrawala, L.; Cheng, A.; Ford, L.; Weidhaas, J.B.; Brown, D.; Bader, A.G.; Slack, F.J. The let-7 microRNA reduces tumor growth in mouse models of lung cancer. Cell Cycle 2008, 7, 759-764. [CrossRef]

246. Trang, P.; Medina, P.P.; Wiggins, J.F.; Ruffino, L.; Kelnar, K.; Omotola, M.; Homer, R.; Brown, D.; Bader, A.G.; Weidhaas, J.B.; et al. Regression of murine lung tumors by the let-7 microRNA. Oncogene 2010, 29, 1580-1587. [CrossRef] [PubMed]

247. Daige, C.; Priddy, L.; Wiggins, J.; Nelligan-Davis, T.; Enzler, D.; Vadnagara, K.; Brown, D. MRX34, a liposomal miR-34 mimic and potential first-in-class microRNA therapeutic: Activity in animal models of liver cancer. J. Clin. Oncol. 2016, 34, e14076. [CrossRef]

248. Beg, M.S.; Brenner, A.J.; Sachdev, J.; Borad, M.; Kang, Y.K.; Stoudemire, J.; Smith, S.; Bader, A.G.; Kim, S.; Hong, D.S. Phase I study of MRX34, a liposomal miR-34a mimic, administered twice weekly in patients with advanced solid tumors. Invest. New Drugs 2017, 35, 180-188. [CrossRef]

249. Humphreys, K.J.; Cobiac, L.; Le Leu, R.K.; Van der Hoek, M.B.; Michael, M.Z. Histone deacetylase inhibition in colorectal cancer cells reveals competing roles for members of the oncogenic miR-17-92 cluster. Mol. Carcinog. 2013, 52, 459-474. [CrossRef]

250. Cameron, E.E.; Bachman, K.E.; Myöhänen, S.; Herman, J.G.; Baylin, S.B. Synergy of demethylation and histone deacetylase inhibition in the re- expression of genes silenced in cancer. Nat. Genet. 1999, 21, 103-107. [CrossRef]

251. Yang, X.; Phillips, D.L.; Ferguson, A.T.; Nelson, W.G.; Herman, J.G.; Davidson, N.E. Synergistic activation of functional estrogen receptor (ER)- $\alpha$ by DNA methyltransferase and histone deacetylase inhibition in human ER- $\alpha$-negative breast cancer cells. Cancer Res. 2001, 61, 7025-7029. [PubMed]

252. Belinsky, S.A.; Klinge, D.M.; Stidley, C.A.; Issa, J.P.; Herman, J.G.; March, T.H.; Baylin, S.B. Inhibition of DNA Methylation and Histone Deacetylation Prevents Murine Lung Cancer. Cancer Res. 2003, 63, 7089-7093. [PubMed]

253. Ecke, I.; Petry, F.; Rosenberger, A.; Tauber, S.; Mönkemeyer, S.; Hess, I.; Dullin, C.; Kimmina, S.; Pirngruber, J.; Johnsen, S.A.; et al Antitumor effects of a combined 5-aza-2' deoxycytidine and valproic acid treatment on rhabdomyosarcoma and medulloblastoma in Ptch mutant mice. Cancer Res. 2009, 69, 887-895. [CrossRef] [PubMed]

254. Steele, N.; Finn, P.; Brown, R.; Plumb, J.A. Combined inhibition of DNA methylation and histone acetylation enhances gene re-expression and drug sensitivity in vivo. Br. J. Cancer 2009, 100, 758-763. [CrossRef] [PubMed]

255. Dowdy, S.C.; Jiang, S.; Zhou, X.C.; Hou, X.; Jin, F.; Podratz, K.C.; Jiang, S.-W. Histone deacetylase inhibitors and paclitaxel cause synergistic effects on apoptosis and microtubule stabilization in papillary serous endometrial cancer cells. Mol. Cancer Ther. 2006, 5, 2767-2776. [CrossRef]

256. Arnold, N.B.; Arkus, N.; Gunn, J.; Korc, M. The histone deacetylase inhibitor suberoylanilide hydroxamic acid induces growth inhibition and enhances gemcitabine-induced cell death in pancreatic cancer. Clin. Cancer Res. 2007, 13, 18-26. [CrossRef]

257. Rikiishi, H.; Shinohara, F.; Sato, T.; Sato, Y.; Suzuki, M.; Echigo, S. Chemosensitization of oral squamous cell carcinoma cells to cisplatin by histone deacetylase inhibitor, suberoylanilide hydroxamic acid. Int. J. Oncol. 2007, 30, 1181-1188. [CrossRef]

258. Kim, M.S.; Blake, M.; Baek, J.H.; Kohlhagen, G.; Pommier, Y.; Carrier, F. Inhibition of Histone Deacetylase Increases Cytotoxicity to Anticancer Drugs Targeting DNA. Cancer Res. 2003, 63, 7291-7300.

259. Gomyo, Y.; Sasaki, J.I.; Branch, C.; Roth, J.A.; Mukhopadhyay, T. 5-Aza-2'-deoxycytidine upregulates caspase-9 expression cooperating with p53-induced apoptosis in human lung cancer cells. Oncogene 2004, 23, 6779-6787. [CrossRef]

260. Shang, D.; Liu, Y.; Liu, Q.; Zhang, F.; Feng, L.; Lv, W.; Tian, Y. Synergy of 5-aza-2'-deoxycytidine (DAC) and paclitaxel in both androgen-dependent and -independent prostate cancer cell lines. Cancer Lett. 2009, 278, 82-87. [CrossRef]

261. Sharma, S.V.; Lee, D.Y.; Li, B.; Quinlan, M.P.; Takahashi, F.; Maheswaran, S.; McDermott, U.; Azizian, N.; Zou, L.; Fischbach, M.A.; et al. A Chromatin-Mediated Reversible Drug-Tolerant State in Cancer Cell Subpopulations. Cell 2010, 141, 69-80. [CrossRef]

262. Knoechel, B.; Roderick, J.E.; Williamson, K.E.; Zhu, J.; Lohr, J.G.; Cotton, M.J.; Gillespie, S.M.; Fernandez, D.; Ku, M.; Wang, H.; et al. An epigenetic mechanism of resistance to targeted therapy in T cell acute lymphoblastic leukemia. Nat. Genet. 2014, 46, 364-370. [CrossRef]

263. Arundel, C.M.; Glicksman, A.S.; Leith, J.T. Enhancement of Radiation Injury in Human Colon Tumor Cells by the Maturational Agent Sodium Butyrate (NaB). Radiat. Res. 2006. [CrossRef]

264. Karagiannis, T.C.; El-Osta, A. Modulation of cellular radiation responses by histone deacetylase inhibitors. Oncogene 2006, 25, 3885-3893. [CrossRef] [PubMed]

265. Karagiannis, T.C.; El-Osta, A. The paradox of histone deacetylase inhibitor-mediated modulation of cellular responses to radiation. Cell Cycle 2005, 5, 288-295. [CrossRef] [PubMed] 
266. Bangert, A.; Cristofanon, S.; Eckhardt, I.; Abhari, B.A.; Kolodziej, S.; Häcker, S.; Vellanki, S.H.K.; Lausen, J.; Debatin, K.M.; Fulda, S. Histone deacetylase inhibitors sensitize glioblastoma cells to TRAIL-induced apoptosis by c-myc-mediated downregulation of cFLIP. Oncogene 2012, 31, 4677-4688. [CrossRef] [PubMed]

267. Butler, L.M.; Liapis, V.; Bouralexis, S.; Welldon, K.; Hay, S.; Thai, L.M.; Labrinidis, A.; Tilley, W.D.; Findlay, D.M.; Evdokiou, A. The histone deacetylase inhibitor, suberoylanilide hydroxamic acid, overcomes resistance of human breast cancer cells to Apo2L/TRAIL. Int. J. Cancer 2006, 119, 944-954. [CrossRef]

268. Lagneaux, L.; Gillet, N.; Stamatopoulos, B.; Delforge, A.; Dejeneffe, M.; Massy, M.; Meuleman, N.; Kentos, A.; Martiat, P.; Willems, L.; et al. Valproic acid induces apoptosis in chronic lymphocytic leukemia cells through activation of the death receptor pathway and potentiates TRAIL response. Exp. Hematol. 2007, 35, 1527-1537. [CrossRef]

269. VanOosten, R.L.; Moore, J.M.; Ludwig, A.T.; Griffith, T.S. Depsipeptide (FR901228) enhances the cytotoxic activity of TRAIL by redistributing TRAIL receptor to membrane lipid rafts. Mol. Ther. 2005, 11, 542-552. [CrossRef]

270. Zhang, X.D.; Gillespie, S.K.; Borrow, J.M.; Hersey, P. The histone deacetylase inhibitor suberic bishydroxamate: A potential sensitizer of melanoma to TNF-related apoptosis-inducing ligand (TRAIL) induced apoptosis. Biochem. Pharmacol. 2003, 66, 1537-1545. [CrossRef]

271. Guo, F.; Sigua, C.; Tao, J.; Bali, P.; George, P.; Li, Y.; Wittmann, S.; Moscinski, L.; Atadja, P.; Bhalla, K. Cotreatment with Histone Deacetylase Inhibitor LAQ824 Enhances Apo-2L/ Tumor Necrosis Factor-Related Apoptosis Inducing Ligand-Induced Death Inducing Signaling Complex Activity and Apoptosis of Human Acute Leukemia Cells. Cancer Res. 2004, 64, 2580-2589. [CrossRef]

272. Fulda, S.; Küfer, M.U.; Meyer, E.; Van Valen, F.; Dockhorn-Dworniczak, B.; Debatin, K.M. Sensitization for death receptor- or drug-induced apoptosis by re-expression of caspase-8 through demethylation or gene transfer. Oncogene 2001, 20, 5865-5877. [CrossRef] [PubMed]

273. Fulda, S.; Debatin, K.M. 5-Aza-2'-deoxycytidine and IFN- $\gamma$ cooperate to sensitize for TRAIL-induced apoptosis by upregulating caspase-8. Oncogene 2006, 25, 5125-5133. [CrossRef] [PubMed]

274. Grotzer, M.; Eggert, A.; Zuzak, T.; Janss, A.; Marwaha, S.; Wiewrodt, B.; Ikegaki, N.; Brodeur, G.; Phillips, P. Resistance to TRAIL-induced apoptosis in primitive neuroectodermal brain tumor cells correlates with a loss of caspase-8 expression. Oncogene 2000, 19, 4604-4610. [CrossRef] [PubMed]

275. Kaminskyyy, V.O.; Surovay, O.V.; Vaculova, A.; Zhivotovsky, B. Combined inhibition of DNA methyltransferase and histone deacetylase restores caspase-8 expression and sensitizes SCLC cells to TRAIL. Carcinogenesis 2011, 32, 1450-1458. [CrossRef] [PubMed]

276. Kurita, S.; Higuchi, H.; Saito, Y.; Nakamoto, N.; Takaishi, H.; Tada, S.; Saito, H.; Gores, G.J.; Hibi, T. DNMT1 and DNMT3b silencing sensitizes human hepatoma cells to TRAIL-mediated apoptosis via up-regulation of TRAIL-R2/DR5 and caspase-8. Cancer Sci. 2010, 101, 1431-1439. [CrossRef] [PubMed]

277. Florean, C.; Schnekenburger, M.; Lee, J.-Y.; Kim, K.R.; Mazumder, A.; Song, S.; Kim, J.-M.; Grandjenette, C.; Kim, J.-G.; Yoon, A.-Y.; et al. Discovery and characterization of Isofistularin-3, a marine brominated alkaloid, as a new DNA demethylating agent inducing cell cycle arrest and sensitization to TRAIL in cancer cells. Oncotarget 2016, 7, 24027-24049. [CrossRef]

278. Weigt, D.; Hopf, C.; Médard, G. Studying epigenetic complexes and their inhibitors with the proteomics toolbox. Clin. Epigenetics 2016, 8, 76. [CrossRef]

279. Huang, P.H.; Plass, C.; Chen, C.S. Effects of histone deacetylase inhibitors on modulating H3K4 methylation marks-A novel cross-talk mechanism between histone-modifying enzymes. Mol. Cell. Pharmacol. 2011, 3, 39-43. [CrossRef] [PubMed]

280. Das, C.; Roy, S.; Namjoshi, S.; Malarkey, C.S.; Jones, D.N.M.; Kutateladze, T.G.; Churchill, M.E.A.; Tyler, J.K. Binding of the histone chaperone ASF1 to the CBP bromodomain promotes histone acetylation. Proc. Natl. Acad. Sci. USA 2014, 111, E1072-E1081. [CrossRef]

281. Huang, J.; Perez-Burgos, L.; Placek, B.J.; Sengupta, R.; Richter, M.; Dorsey, J.A.; Kubicek, S.; Opravil, S.; Jenuwein, T.; Berger, S.L. Repression of p53 activity by Smyd2-mediated methylation. Nature 2006. [CrossRef]

282. Day, J.J. New approaches to manipulating the epigenome. Dialogues Clin. Neurosci. 2014, 16, 345-357.

283. Geel, T.M.; Ruiters, M.H.J.; Cool, R.H.; Halby, L.; Voshart, D.C.; Andrade Ruiz, L.; Niezen-Koning, K.E.; Arimondo, P.B.; Rots, M.G. The past and presence of gene targeting: From chemicals and DNA via proteins to RNA. Philos. Trans. R. Soc. B Biol. Sci. 2018, 373, 20170077. [CrossRef] [PubMed]

284. Tye, K.M.; Deisseroth, K. Optogenetic investigation of neural circuits underlying brain disease in animal models. Nat. Rev. Neurosci. 2012. [CrossRef]

285. Cano-Rodriguez, D.; Gjaltema, R.A.F.; Jilderda, L.J.; Jellema, P.; Dokter-Fokkens, J.; Ruiters, M.H.J.; Rots, M.G. Writing of H3K4Me3 overcomes epigenetic silencing in a sustained but context-dependent manner. Nat. Commun. 2016, 7, 12284. [CrossRef] [PubMed]

286. Mlambo, T.; Nitsch, S.; Hildenbeutel, M.; Romito, M.; Müller, M.; Bossen, C.; Diederichs, S.; Cornu, T.I.; Cathomen, T.; Mussolino, C. Designer epigenome modifiers enable robust and sustained gene silencing in clinically relevant human cells. Nucleic Acids Res. 2018, 46, 4456-4468. [CrossRef] [PubMed]

287. Tsai, H.C.; Li, H.; Van Neste, L.; Cai, Y.; Robert, C.; Rassool, F.V.; Shin, J.J.; Harbom, K.M.; Beaty, R.; Pappou, E.; et al. Transient Low Doses of DNA-Demethylating Agents Exert Durable Antitumor Effects on Hematological and Epithelial Tumor Cells. Cancer Cell 2012, 21, 430-446. [CrossRef] [PubMed] 